\title{
Non-Wood Forest Products Based on Extractives- A New Opportunity for Canadian Forest Industry
}

\section{Part 2- Softwood Forest Species}

\author{
Mariana Royer ${ }^{1,2}$, Robert Houde ${ }^{3}$ \& Tatjana Stevanovic ${ }^{1,2}$ \\ ${ }^{1}$ Département des sciences du bois et de la forêt, Université Laval, 2425 Rue de la Terrasse, Québec G1V0A6, \\ Canada \\ ${ }^{2}$ Institut sur la nutrition et les aliments fonctionnels, Université Laval, Québec \\ ${ }^{3}$ Agro-Kimika Concepts, 626 Strathmore Blvd Dorval, Québec H9P 2A2, Canada \\ Correspondence: Tatjana Stevanovic, Département des sciences du bois et de la forêt, Université Laval. Tel: \\ 1-418-656-2131 ext. 7337. E-mail: tatjana.stevanovic@sbf.ulaval.ca
}

\author{
Received: May 31, 2013 Accepted: September 10, 2013 Online Published: September 20, 2013 \\ doi:10.5539/jfr.v2n5p164 URL: http://dx.doi.org/10.5539/jfr.v2n5p164
}

\begin{abstract}
Forest resources are among the most important of Canada (in the case of Quebec, nearly 90\% of the territory). Innovation represents an essential challenge for the Canadian forest industry, which is presently undergoing major changes towards finding new solutions for recovery. The processing of forest biomass has become increasingly relevant along with the popular concept of biorefineries. This concept should include the development of novel technologies based on forest extractives. Bioactive molecules are readily available through eco-friendly extraction processes using various types of forest residues including barks which are generated in significant quantities by the industry. This literature review offers a glimpse into the softwood boreal forest with a particular focus on industrial species. We are adopting an ethno-pharmacological approach prior to presenting existing data on bioactive molecules from various sources, along with results from our own laboratory. In conclusion, this paper clearly demonstrates the need for further research on bioactive molecules from Canadian forest species since there remains an important lack of reliable data.
\end{abstract}

Keywords: Canadian softwood species, extractives, terpenes, polyphenols, traditional uses, bioactivities

\section{Introduction}

The forest has played a major role in the history of Canada and Québec. Trees are ubiquitous in the collective imagination of Canadian people and wood products are omnipresent in everyday life. Wood represents a true heritage which plays a significant role at multiple levels: economic, social, cultural, recreational, and finally, very importantly, ecological. As previously stated in Part 1 of this comprehensive review on extractives from available Canadian forest species (Royer, Houde, Viano, \& Stevanovic, 2012), the Canadian forest industry is currently undergoing a crisis due to sharp decreases in supply and demand from both the United States and Canada, a situation that brought a dramatic drop in lumber and newsprint prices. Production, employment, exports and profits have almost all plummeted. In this context, the Québec Ministry of Natural Resources and Wildlife, in its Green Paper titled "The forest: building the Québec of tomorrow" (MRNF, 2008), is proposing a developmental strategy focused on novel, high-value industrial products aiming at (i) promoting an innovative industry that creates wealth and sustainable employment and (ii) promoting enhanced public awareness of this precious resource in a wider sense. Novel technologies enabling forest biomass valorization are of particular interest for Québec and Canada. The newly developing industrial sector described as "forest extractives" represents an irrevocable step in this direction. This pursuit requires the design of comprehensive programs leading to the identification and application of compounds extracted in significant quantities from residues generated at all stages of the forest industry, and particularly from its most abundant residue - bark. The latter is a by-product of the primary processing industry. According to official statistics from the Québec Ministry of Natural Resources and Wildlife (MRNF), bark production and importation reached more than 2.4 million metric tonnes in 2008 (Parent, 2009). This material is commonly either burned to meet the energy needs of lumber and 
pulp and paper plants, or simply buried on-site; the latter practice actually raises environmental issues such as leaching and groundwater pollution. However, bark is rich in valuable extractives and especially in polyphenolic compounds that are well-known for their versatile biological properties (Stevanovic, Diouf, \& Garcia-Perez, 2010). Global demand for various bioproducts derived from renewable resources is growing rapidly, partly due to new consumer trends (social and cultural changes) and the search for sustainable alternatives in relation to energy sources. A greater impact of various "green" trends in the media, and the increasing number of distribution channels are also important growth factors. The birth of the sector designated as "forest extractives" implies building a bridge between two important sectors of the Québec economy: the wood sector on one hand, and the chemical industry on the other hand. Indeed, Québec's forest industry is in crisis but turns out large volumes of raw materials known to be rich in bioactive natural molecules, and the industry holds the expertise on efficient harvesting and storage of those materials. As for the chemical industry, it holds a more favorable economic position and has already taken the sustainability turn, in terms of re-engineering and green chemistry principles; besides, chemical players benefit from their cutting edge processes and technologies. The integrated development of this forest extractives new sector will also require optimized new processes to upgrade and add value to important volumes of residual materials remaining post-extraction.

Conifers are part of the Pinopsidae class within the Pinophytae division of gymnosperms, which also include most primitive groups belonging to Cycas or Ginkgos. Their seeds are often located at the base of woody scales grouped as cones. Most conifers harbour resin-secreting cells in their bark, foliage or wood. Conifers cover roughly $75 \%$ of the boreal forest throughout Québec from east to west, over 560,000 square kilometers. The dominant species is black spruce (Picea mariana), the life span of which can exceed 200 years with heights reaching 25 meters. Other conifer species which occupy significant areas of natural stands, are Jack pine (Pinus banksania), balsam fir (Abies balsamea), white spruce (Picea glauca) and tamarack larch (Larix laricina- at times called "red spruce") .

\section{Forest Extractives From Canadian Softwood Species of Commercial Interest}

Table 1 lists the conifers studied in this second part of the review.

Table 1. List of conifers considered this review

\begin{tabular}{ll}
\hline Softwood species & Botanical name \\
\hline Spruce & Picea spp. \\
Pine & Pinus spp. \\
Larch & Larixspp. \\
Fir & Abies spp. \\
Hemlock & Tsuga spp. \\
Thuya & Thuja spp. \\
\hline
\end{tabular}

\subsection{Spruce: Genus Picea}

\subsubsection{The Various Spruce Species Found in Canadian Forests}

Nine species belong to the Picea genus in Canada, six of which are indigenous. Black spruce (Picea mariana) is the most widespread conifer species in Canadian forests. Peatland forests usually dominated by black spruce account for roughly $25 \%$ of the productive forested land in the central portion of the Boreal Shield Ecozone ("peatland black spruce").

- $\quad$ Black spruce (P. mariana)

- $\quad$ Blue spruce (P. pungens)

- $\quad$ Colorado spruce (P. pungens)

- $\quad$ Engelmann spruce (P. engelmannii)

- $\quad$ Norway spruce and Norway spruce (P. abies)

- $\quad$ Red spruce (P. rubens)

- $\quad$ Serbian spruce (P. omorika) 


\section{- $\quad$ Sitka spruce (P. sitchensis)}

- $\quad$ White spruce (P. glauca)

Three species are considered native to Québec: white spruce (Picea glauca), black spruce (Picea mariana) and red spruce (Picea rubens). Norway spruce (Picea abies) was introduced around 1915 and planted in Canadian forests since. This species has enjoyed great popularity due to its high productivity in plantations, usually exceeding the performance of native species (Daoust, 1999). Spruce species suffer from the threat of budworm, and in Québec this predator is widespread throughout the distribution area of its main hosts and favorite species, namely white spruce, red spruce, black spruce and balsam fir.

\subsubsection{Common Uses of Picea in the Forest Industry}

\subsubsection{White Spruce (P. glauca)}

White spruce remains one of the species most favored in reforestation works, while other applications include construction lumber, pulp and paper, as well as in the manufacture of musical instruments. White spruce grown and harvested in plantations usually comprises a higher proportion of juvenile wood compared to wood from natural stands, largely because of its early harvesting. This is known to lower the quality of lumber produced from plantations, particularly when harvested after drought (Beaulieu, Girarda, \& Fortin, 2002).

\subsubsection{Black Spruce (P. mariana)}

This species of significant economic importance dominates the boreal forest of Eastern North America. Present throughout areas of commercial forests, its unique qualities (long fibers, high density) are sought by the forest industry to manufacture sawing lumber, and also in pulp and paper production since its fibers yield excellent newsprint quality. As well, P. mariana remains the most widely used species in reforestation programs.

\subsubsection{Red Spruce (Picea rubens)}

Red spruce wood is pale brown or cream-colored, relatively soft and moderately resistant. It is found in lumber and plywood panels, and its low resin content makes it a prime choice for pulp and paper manufacturing. Red spruce and black spruce naturally cross-pollinate, giving rise to individuals with intermediate characteristics. Picea rubens is known for its poor wind resistance, and its susceptibility to spruce budworm. Natives asked to locate red spruce will often point to larch, this has thus often led to some ambiguities in the literature.

\subsubsection{Norway Spruce (Picea abies)}

Norway spruce is recognized for its high productivity in plantations, and as superior in every way to white spruce since it remains unaffected by the weevil predator. Its rapid growth, flexible stem and normally thinner branches could explain its productivity in sawmill operations, both in terms of volume and of quality. Additionally, in good quality stands the deformations sometimes observed in young plantation individuals greatly decrease over time since this species has a remarkable ability to correct defects.

\subsubsection{Picea Traditional Uses}

The ethnopharmacological study conducted by Arnason et al. (Arnason, Hebda, \& Johns, 1981) has collected extensive data on this species. Several Native American First Nations consumed the gum-resin of various spruce species for chewing. Young shoots were sometimes prepared as decoctions to treat coughs; on the basis of their expectorant and diaphoretic qualities they can even nowadays be added to bath water for their sedative benefits. They have depurative properties and are slightly purgative. Interestingly, a beer brewed with buds from available spruce species was reported to treat tuberculosis. The bark was also used in the preparation of medicinal potions. In Québec, the gum was considered a powerful antiscorbutic, a prodigestiveaid and also a remedy against seasickness. People chewed it, or used it as a tincture by dissolving it in alcohol. Nowadays commercially available fir or spruce syrups are consumed for their expectorant qualities. In Europe, a spruce species - Picea abies - was commonly used in medicinal baths to treat rheumatisms and nervous disorders; to this effect, young shoots and needles of 60 to 80 year old trees were preferably harvested for their inherently high concentration of active ingredients.

Table 2 summarizes the main ethnopharmacological data published by Arnason et al. (Arnason et al., 1981) with regards to the Picea genus in Québec. Reported therapeutic uses of any particular forest species often yield valuable information to help identify bioactive components of extractives, for future applications in nutrition, cosmetics, cosmeceuticals, pharmaceuticals, etc. 
Table 2. Ethnopharmacological data compiled on genus Picea (Adapted from Arnason et al., 1981)

\begin{tabular}{|c|c|c|c|c|}
\hline Species & First Nation & Part of the tree & Method & Curative purpose \\
\hline \multirow[t]{6}{*}{ Picea sp. } & \multirow[t]{3}{*}{ Iroquois } & Gum & & tuberculosis \\
\hline & & Leaves & fumigator & inhalant \\
\hline & & Twigs & $\begin{array}{l}\text { twigs mixed with } \\
\text { ground pine moss and Ostrya } \\
\text { (ironwood) }\end{array}$ & rheumatism \\
\hline & \multirow{4}{*}{ Ojibway } & Bark and root & tea & stomach pain, fainting \\
\hline & & Needles & tea & $\begin{array}{l}\text { "heal the insides" after } \\
\text { childbirth }\end{array}$ \\
\hline & & Internal bark & infusion & Cough remedy: \\
\hline \multirow{12}{*}{$\begin{array}{l}\text { Picea } \\
\text { glauca }\end{array}$} & & Resin & $\begin{array}{l}\text { chewed; salve } \\
\text { gum; chew gum }\end{array}$ & laxative \\
\hline & Montagnais & Twigs & Steeped & general tonic \\
\hline & Abenaki & $\begin{array}{l}\text { Gum and green cone } \\
\text { No part given }\end{array}$ & infusion & $\begin{array}{l}\text { frequent urination } \\
\text { stomach trouble }\end{array}$ \\
\hline & Maritime & $\begin{array}{l}\text { Bark, } \\
\text { gum, twigs }\end{array}$ & & scabs, wounds, sores \\
\hline & \multirow{4}{*}{ Cree } & Resin & $\begin{array}{l}\text { gum } \\
\text { gum applied }\end{array}$ & $\begin{array}{l}\text { salve, laxative } \\
\text { sores }\end{array}$ \\
\hline & & Cone & jelly & $\begin{array}{l}\text { headache, } \\
\text { stomachache }\end{array}$ \\
\hline & & Leaves & leaf tea & reviver \\
\hline & & Bark & bark tea & laxative \\
\hline & \multirow{4}{*}{ Ojibway } & Bark & crushed, heated, and inhaled & backache \\
\hline & & Leaves & crushed and applied & headache \\
\hline & & $\begin{array}{l}\text { Bark } \\
\text { and root }\end{array}$ & tea & stomach pain, fainting \\
\hline & & Needles & tea & "heal the insides" \\
\hline \multirow[t]{6}{*}{$\begin{array}{l}\text { Picea } \\
\text { mariana }\end{array}$} & Algonquin & Resin & $\begin{array}{l}\text { gum salve } \\
\text { chew gum } \\
\text { boil with }\end{array}$ & $\begin{array}{l}\text { After childbirth } \\
\text { laxative }\end{array}$ \\
\hline & Algonquin & No part given & $\begin{array}{l}\text { Pyrus americana, Picea } \\
\text { glauca, Sambucus canadensis, } \\
\text { Gaultheria procumbens }\end{array}$ & Blood tonic \\
\hline & Montagnais & Twigs & boil & \multirow{3}{*}{$\begin{array}{l}\text { Cough medicine } \\
\text { sores }\end{array}$} \\
\hline & Micmac & Bark & no method given & \\
\hline & \multirow[b]{2}{*}{ Cree } & Resin & applied gum & \\
\hline & & Cones & jelly & $\begin{array}{l}\text { headache, } \\
\text { stomachache }\end{array}$ \\
\hline $\begin{array}{l}\text { Picea } \\
\text { rubens }\end{array}$ & Montagnais & Bark & $\begin{array}{l}\text { boil bark } \\
\text { with roots of sour grass, drink }\end{array}$ & lung, throat trouble \\
\hline
\end{tabular}

As seen in Table 2, traditional uses for red spruce are absent likely because First Nations people often confuse this species with the indigenous larch (Larix laricina). More recently, a study titled "The red spruce: from traditional to contemporary uses" put together unique data on traditional uses for this species (Chartier, 2009 212). The study reveals that several applications were in fact similar to those observed with other native species to Québec: for example the use of red spruce gum on sores or painful areas (backache), the preparation of bark decoctions for lung and throat problems, for "purification" of the blood and intestines, and uses in postpartum (toning). 


\subsubsection{Current Knowledge on Picea Extractives and Their Biological Properties}

Most of the scientific data available on the genus Picea comes from European studies, focusing mainly on the phytochemistry of the Norway spruce (P. abies). Polyphenolic compounds represent one of the major classes of extractives studied in this species, with extraction of the bark tissue affording yields exceeding $10 \%$ (on an oven dry mass basis).

Chemical analysis was performed on the neutral fraction from the petroleum ether extract of Sitka spruce (Picea sitchensis) bark (Roger, 1967), and the results revealed a high concentration of compounds from the triterpene class. Around the same period, polyphenolic compounds were studied for the first time in the bark of several Canadian species: Manners and Swan were the first to successfully isolate three stilbenes from the bark of several spruce species from Canadian forests namely Engelmann spruce ( $P$. engelmannii), white ( $P$. glauca), black (P. mariana), red (P. rubens) and Sitka (P. sitchensis) (Manners \& Swan, 1971).

Table 3. Yields of extractives in spruce bark extracts enriched in stilbenes after acetone extraction (Adapted from Manners \& Swan, 1971)

\begin{tabular}{ll}
\hline Species & \% Yield \\
\hline Picea mariana & $4.93 \%$ \\
Picea glauca & $6.28 \%$ \\
Picea rubens & $6.47 \%$ \\
\hline
\end{tabular}

Stilbenes are dibenzylpolyphenolic compounds biosynthesized by several unrelated plant families and which appear to protect against various biotic and abiotic stresses. Three of those - astringin, isorhapontin and isorhapontigenin- can be related to some defense mechanism against fungal infection (Hammerbacher et al., 2011), (Witzell \& Martin, 2008). The repellent and termiticidal activities (Shibutani, Samejima, \& Doi, 2004) of stilbenes have been demonstrated along with their inhibition of fungal enzymes secreted to degrade wood cellulose (Shibutani, Igarashi, Samejima, \& Saburi, 2001). Stilbenes- being derivatives of resveratrol - are potent antioxidants and have been shown to prevent cardiac diseases (Fauconneau et al., 1997), (H. -L. Li et al., 2005), (Mérillon et al., 1997). An investigation into their relative distribution in tree tissues revealed their abundance in the bark, with lower contents measured in roots, needles or sap (Toscano, Underwood, \& Pearce, 1991). A fourth stilbene glycoside, astringenin, has been isolated from white spruceand also found in trace amounts in the bark of red and black spruce. In an earlier study, hydroxystilbenes were isolated via sequential bark extraction using acetone followed by re-solubilization of the dehydrated acetone extract in methanol and finally purification by washing the methanolic solution with petroleum ether (Manners \& Swan, 1971); this last step allowed for the elimination of lipophilic terpene compounds and yielded the target polyphenolic compounds, mostly stilbenes (Table 3). Recent work in Finland established that a stilbene-rich extract (95-98\% purity) from Norway spruce bark could be obtained by simply using ethanol as solvent (Wood Biocon, 2007) and further revealed that the $P$. abies outer bark composition differs significantly from that of the inner bark: the latter contains more active stilbenes than the outer bark. Furthermore, the composition of the active stilbene-rich fraction only varies slightly according to the bark harvesting season. Paying due attention to such differences is essential when designing specific industrial applications which ultimately depend on the type or quality of the extract. In 2008, over 60 different known types of phenolic compounds had been isolated from various tissues (bark, wood, woodknots, needles, cones) of the Norway spruce, Picea abies and the latter remainsby far the most investigated species nowadays (Li et al., 2008, Lindberg, Willför, \& Holmbom, 2004; Pan \& Lundgren, 1995; Roy \& Bergeron, 1990). We included these data in the present review because plantation-grown $P$. abiesspecies is harvested by the forest industry in Québec for its specific qualities (Mottet \& Daoust, 2007). Besides stilbenes, spruce bark extracts have been shown to contain other polyphenolic compounds such as flavonoids (catechin, epicatechin and taxifolin), proanthocyanidinsor condensed tannins (Tišler, Galla, \& Pulkkinen, 1986) and lignans (hydroxymatairesinol) (Pan \& Lundgren, 1995). Work by Pietarinen et al. demonstrated that $P$. abies bark extracts exhibit the highest capacity to inhibit lipid peroxidation when compared with other bark extracts such as Betula pendula, Thuja occidentalis, Pinus banksania and also standardized Pycnogenol ${ }^{\mathbb{B}}$ which is the main commercial polyphenol-rich maritime pine bark extract (Pietarinen, Willför, Ahotupa, Hemming, \& Holmbom, 2006). The antioxidant properties of extracts from white spruce bark and from black spruce foliage were also measured by McCune (McCune \& Johns, 2002) and theirresults confirm that such extracts represent valuable natural candidates either as food additives or as natural preservatives in cosmetic products where the inhibition of lipid 
rancidity is required. Interestingly,a study has confirmed that both black ( $P$. mariana) and white $(P$. glauca) spruce wood and knots contain lignans which possess multiple bioactivities including significant antioxidant power (Willför et al., 2005)). Young shoots from white spruce (P. glauca) were subjected to chemical analysis and their detailed polyphenolic composition revealed (Kraus \& Spiteller, 1997).

Beyond antioxidative properties, other biological activities are linked to the presence of polyphenols in bark extracts. Two research groups independently demonstrated significant antifungal activities in extracts from white spruce (P. glauca) and Norway spruce (P. abies) barks (Evensen, Solheim, Høiland, \& Stenersen, 2000; Yang, Wang, \& Hui Wan, 2004). Extracts from white spruce (P. glauca) heartwood and from its inner bark were shown to possess antimicrobial activities against several bacterial strains namely E. coli, Staphylococcus aureus, and Pseudomonas aeruginosa (Ritch-Krc, Turner, \& Towers, 1996). A comprehensive study on boreal plants used by Cree First Nations revealed that white spruce needles possess some cytoprotective activity against both glucose toxicity and glucose deprivation (Harbilas et al., 2009).

Our review of bibliographical data relative to the genus Picea pointed to a lack of information on the chemical composition of extracts from black spruce (P. mariana) and from red spruce (P. rubens). Recent work carried out by our research group focused more specifically on polyphenolic compounds in bark extracts from black spruce $(P$. mariana) (García-Pérez et al., 2010). Few studies investigated the chemistry of leaves and needles (Friedland, Hawley, \& Gregory, 1988). Changes in antioxidant activities per season of harvest in red spruce needle extracts were also demonstrated in a 1991 paper (Madamanchi, Hausladen, Alscher, Amundson, \& Fellows, 1991).

Working with various species of spruce, in particular Picea abies, T. Norin successfully isolated and identified a series of lipophilic constituents: terpenes, fatty acids and alkanes (Norin, 1972). With regards to lipophilic extractives from Canadian Picea species, resin acids isolated from the phloem resin of white spruce (P. glauca) were shown to play an important role in the resistance of this tree against attacks by pathogens and insects, synergistically with polyphenols (Kersten, Kopper, Raffa, \& Illman, 2006). A study that included white spruce also identified terpenes as agents responsible for the resistance of Picea species against weevils (Manville, Nault, \& Sahota, 1999). There remains a scarcity of contemporary data on (i) the terpenoid profile of Québec native spruce bark, and (ii) on the composition of essential oil sex tractable from other parts.

\subsubsection{Spruce Essential Oil}

A wide variety of conifers including spruce have been the object of studies trying to elucidate the composition and properties of their respective essential oils. The latter are mostly composed of terpenoids and polyphenols. In the majority of cases, these oils are obtained by hydrodistillation of needles but also from other tissues, such as leaves and bark. In the course of the current literature review, no data became available on the yields of essential oils for different parts of the tree. It is well known that yields are generally low and vary typically between 0.5 to $2 \%$ of the dried raw material. Von Rudloff investigated seasonal variations in the volatile oil composition from leaves, buds, and twigs of white spruce (Rudloff, 1972); the same author determined that the yield of steam-volatile oil (around $0.5 \%$ ) was the highest in young twigs and the lowest in older leaves, and that any major change in volatile oil from the foliage had taken place only during new growth in May and June.

In Québec, the essential oil of black spruce ( $P$. mariana) as obtained from needles or leaves (the most available parts) is widely marketed and trusted for its therapeutic properties (tonic for bronchial, joint or rheumatoid pain) ("Essential Oil Profile: Black Spruce," 2011). Black spruce needle oil contains camphene (19\%), $\alpha$-pinene (15\%), 3-carene, longifolene, bornyl acetate (42-52\%), santene, myrcene, limonene and longiborneal, a sesquiterphenol. Yields hover around $1.4 \%$ - the highest being observed in April needles. Another report indicates that bud essential oil contains more than $50 \% 3$-carene, $25 \%$ of $\alpha$ - and $\beta$-pinene as well as terpinolene $(4.7 \%)$ (Frost). The maximum yield reported reached $0.2 \%$. Compounds identified in twig oil by the author were almost identical to those identified in bud oil, albeit with lower concentrations of bornyl acetate and limonene.

Essential oil obtained from White spruce needles contains camphor (40\%), limonene (15.3\%), bornyl acetate $(12.1 \%)$, and smaller amounts of camphene, $\alpha$ - and $\beta$-pinene, and myrcene. Yields reached about $0.2-0.5 \%$, with the highest being observed in April material. Bud essential oil contained over $40 \% \alpha$ - and $\beta$-pinene, over 30\% myrcene, and $9 \%$ of 3 -carene, the latter constituent not present in needle oil. The yield from buds was around $0.5 \%$. Finally, oil obtained from twigs revealed a different compositional profile: limonene (37.5\%), $\alpha$-pinene (22\%), myrcene and $\beta$ - pinene; yields reported by Frost were $0.5-0.7 \%$.

According to Frost, essential oils from spruce possess anti-spasmodic, antifungal and anti-parasitic properties. They reduce inflammation and show hormone-like activity: stimulating the thymus gland and the adrenals. It is accepted as an all-around tonic and an energizer for the nervous system and solar plexus. However, no detailed scientific studies on the biological properties of essential oils from Canadian Picea species appear to be available. 
Recently, the antioxidant activities of essential oils from several Picea species have been screened and compared with those from other genera (Saleh, Clark, Woodard, \& Deolu-Sobogun, 2010).

Several types of essential oils are distilled in Canada; still many aromatherapists have yet to discover their remarkable properties and fragrances. For instance, under proper supervision they may be applied to treat skin conditions such as acne, psoriasis and dry eczema; the essential oil of white spruce ( $P$. glauca) exhibits a characteristic tonic effect and is apparently efficient in the treatment of psoriasis whereas in aromatherapy it targets pulmonary health.

The oil obtained from red spruce needles is reported to be neurotonic and anti-infectious, while the one derived from white spruce needles has been known to treat influenza, lung problems and relieve women`s pain after delivery. Essential oils in general are widely known for their antimicrobial activity, and at times may exhibit significant antioxidant activity. Recently, Chartier compared the terpenic composition of essential oils obtained from three species native to Québec (Chartier, 2009), P. mariana, P. rubens and P. glauca. The author demonstrated that the nature of monoterpenes in those essential oils is very similar; however the bioactivity levels vary from one species to the other.

In an effort to better understand the huge potential of the upcoming sector extractives within Quebec's global forest industry, one should consider the complete range of extractives that can be exploited, which include essential oils obtained by hydrodistillation. However, low yields obtained with this technique often negatively affect feasibility parameters, should the focus of the program remain strictly on the oil for industrial development. However, available data on yields from bark extraction with either water or organic solvents indicate that those vary in the $15-25 \%$ range (dried material basis) in several Canadian species.

\subsubsection{Results Obtained in Our laboratory on Spruce Extractives and Their Biological Properties}

Our research group has spearheaded studies on the polyphenolic composition of bark extracts from black spruce (Picea mariana), as well as their biological properties.

In 2009, Diouf et al. characterized proanthocyanidins (condensed tannins) present in a bark extract obtained through hot water extraction under reflux (Diouf, Stevanovic, \& Cloutier, 2009). The fraction high in oligomeric proanthocyanidins is a valuable and confirmed source of natural antioxidants with potency similar or higher than the synthetic antioxidant BHT (butylated hydroxytoluene). This study also demonstrated the anti-inflammatory activity of the proanthocyanidin-rich fraction and the fact that other polyphenols may be responsible for the measured biological properties, for instance the flavonoid taxifolin. Those results suggest that the crude aqueous extract from black spruce bark could be used without purification, a factor to consider when designing for large-scale production of a biomass-derived product for various end markets. Further investigations are required to better understand key aspects such as the bioavailability and in vivo potential interactions of the active constituents.

A paper published by Garcia-Perez et al. focused on the most active bark extracts obtained from various Canadian species, as potential key ingredients in anti-psoriatic treatments (García-Pérez et al., 2010). The aqueous extract from black spruce bark was singled out as the best candidate for such an application. This extract not only exhibited the strongest antioxidant activity among a series of 12 extracts from the boreal forest, but also demonstrated the lowest toxicity against normal human skin cells. High anti-inflammatory activity was observed as well, besides the capacity to inhibit cell proliferation, the latter being a critical phenomenon in psoriasis pathology. In a subsequent study, this bioactive extract was purified by liquid-liquid extraction and the chemical composition of the purified ethyl acetate fraction was established (García-Pérez et al., 2012). A total of 28 compounds were isolated and identified by Nuclear Magnetic Resonance (NMR). Results reported in that study represent the most detailed description of a black spruce bark extractive to date. Constituents identified in the ethyl acetate fraction included several classes of polyphenols known for their strong biological properties: lignans and neolignans, phenolic acids, flavonoids and stilbenes. The authors further concluded that black spruce bark could be considered as a practical new source of trans-resveratrol, a stilbene extensively studied in the literature. This powerful antioxidant, also found, for instance, in grape seed and peanut skin, is recognized for its beneficial properties against symptoms of aging. Stilbenes are also generally regarded as important constituents contributing to the natural durability of quality woods.

\subsection{Pine: Genus Pinus}

\subsubsection{The Diversity of Species in Canada}

There are no less than sixteen species within the genus Pinus identified in Canada, including four introduced species: Pinus aristata, Pinus mugo, Pinus nigra and Pinus sylvestris, the latter now recognized as a fully 
naturalized species.

- Bhutan pine (P. wallichiana)

- Chilean pine (P. radiata)

- European black pine (P. nigra)

- Jack pine (P. banksiana) Limber pine (P. flexilis) Lodgepole pine (P. contorta var. Contorta)

- Lodgepole pine (P. contorta var. Latifolia)

- Mugo pine (P. mugo) Pitch (P. rigida)

- Ponderosa pine (P. ponderosa)

- Red Pine (P. resinosa)

- Rocky Mountain Bristlecone pine (P. aristata)

- Scots pine (P. sylvestris)

- Western white pine (P. monticola)

- White pine (P. strobus) White bark pine (P. albicaulis)

Among the main species observed in Canadian forests are red pine, white pine and Jack pine. They represent the most common species in the boreal zone, especially in balsam fir-white birch forests, and they reach their limit in the spruce-lichen zone. White and red pine are mostly found in deciduous forest, in the maple-yellow birch sub-area (MRNF, 2008).

\subsubsection{Common Uses of Pinus by the Forest Industry}

\subsubsection{Jack Pine (P. banksiana)}

Widely distributed in the regions of Abitibi, Northern Mauricie and Saguenay-Lac-St-Jean, this species is also planted everywhere in the province. In excess of 2.5 million tons of pine round wood are processed annually in Québec (FPInnovations, 2000). Jack pine wood contains less resin than other Pinus species. With its low shrinkage rate, it exhibits good dimensional stability when properly dried; its very low natural durability (below that of white cedar) is still considered higher than that of white spruce, for example. Pine heartwood features low permeability and hence resistance to impregnation. Common uses include poles, posts, fences, gates, moldings, floors, stairs, edge-glued panels, doors \& windows, shelves, etc. (Giguère, 2008). Jack pine wood can also be treated at high temperatures.

\subsubsection{Red Pine (P. resinosa)}

Red pine was one of the first species commercially exploited in North America. From 1670 on, the steward named Talon kept ordering the harvesting of this species for shipbuilding. Red pine wood is redder and more resinous than wood from white pine and also well recognized for its hard, lightweight and durable qualities. It finds uses mostly for framing, poles, boxes, doors \& windows, pegs, railroad ties, pulp and paper, etc. Its average natural durability when in contact with the ground usually requires treatment with preservatives. Despite some strong shrinkage, its wood is considered easy to dry. Red pine has been widely popular in plantations in Québec and those plantations have been among the most productive; still, these days the practise of planting red pine has been all but discontinued because of the poor market for small- and medium-size timber.

\subsubsection{White Pine (P. strobus)}

With its exceptional longevity (200-400 years) white pine is considered the most majestic tree of eastern Canada. Commercial products from white pine have high economic value and remain in great demand. Abundant in the early $20^{\text {th }}$ century, white pine was commonly used to build houses, docks and vessels including masts, and for various commercial structures as well as in art works. Resources gradually declined over the years, and today roughly $90 \%$ of the available resources are located in the Outaouais and Abitibi-Témiscamingue regions, but white pine lumber still remains the most sought after. The scarcity of this raw material and pricing of its finished products have contributed to the development of several alternatives, such as in frames and moldings.

\subsubsection{Pinus Traditional Uses}

Species belonging to the Pinaceae family have been popular in folk medicine for various treatments. Among the species native to Québec, eastern white pine ( $P$. strobus) and red pine ( $P$. resinosa) were included by Jacques Rousseau among the eight conifer species representing the mythical "Annedda" or "tree of life" (Rousseau, 1954). This mysterious "tree of life", described as a tall tree in the Québec region that keeps its foliage in winter, 
cured scurvy in several members of Jacques Cartier's team of explorers during their second journey to Canada in 1536. Indeed, desperate to cure this disease which he considered endemic, Cartier consulted First Nations members and was apparently advised by an Iroquois to prepare a bark and leaf decoction of the "Annedda" tree, which is now associated with the arborvitae family (such as Thuja) (Durzan, 2009). Wyandotes and Mohawks called white pine (P. strobus) handehta and ohnehda respectively. Hurons named a yet unidentified species of pine (both red and white pine) andeta or ondata. In his research on the possible identity of this tree of life, Jacques Rousseau excluded Jack pine ( $P$. banksiana) although the latter was present about 50 kilometers downstream from the site where the Cartier team hibernated at the time episodes of scurvy were reported.

\subsubsection{Jack Pine (P. banksiana)}

Indigenous peoples of North America developed extensive knowledge about several species from the boreal forest - P. banksiana among them - with regards for instance to their anti-inflammatory properties. Boiled cones were processed into an anti-inflammatory balm, while the leaves were used in aromatherapy to treat comatose patients and to "clear" congested lungs. The gum from this species was chewed to treat colds and its taste considered highly desirable. Crushed and boiled inner bark was made into a poultice and applied on wounds. Unprocessed bark was consumed as well (Kuhnlein \& Turner, 1991) whereas the essential oil and resin found uses as disinfectants, antiseptics and insecticides (Burchill, 2008). Breathing problems were addressed using an infusion made from bark (Karst, 2010). The Arnason review mentions multiple traditional uses of red pine $(P$. resinosa) and white pine (P. strobus) (Arnason et al., 1981). Only the Ojibwa First Nations developed applications for Jack pine ( $P$. banksania), the leaves of which they used as a tonic along with bark decoctions, also in mixtures with other species including white pine (P. strobus).

\subsubsection{Red Pine (P. resinosa)}

This particular species ( $P$. resinosa) has been recognized by several indigenous nations for its practical therapeutic properties. Algonquins prepared the inner bark as a poultice, to place on one's chest when treating influenza, while the Ojibwas dried and crushed the leaves into a powder either to inhale or to prepare into a tonic against headaches. Interestingly, members of the Cree Nation were preparing smoke from the leaves to wake patients up from coma, and also cured the flu with a poultice made from the inner bark (Arnason et al., 1981; Moerman, 1986).

\subsubsection{White Pine (P. strobus)}

Aboriginals considered white pine (P. strobus) as a valuable source of medicinal principles. Besides consuming the extract from boiled inner bark (rich in astringent tannins) for treating diarrhea, they mostly soaked the bark for applying on wounds due to its healing effect and antiseptic properties (Arnason et al., 1981). Abenakis, Crees and Maritimes also used the inner bark as a cough remedy or as a decoction or poultice on the chest. Bark decoctions were also recommended in cases of general body weakness, albeit in combination with other species. Needle infusion has been considered for some time as "rich in vitamins" and thus useful in preventing the flu (Table 4). Arnason remarks that Ojibwa Nations used mainly the cones, bark and dried leaves to treat flu symptoms, whereas for treating injuries they resorted to applying a wet paste made from pieces of sapwood and bark, boiled and mixed together. The following table summarizes the data collected so far on the traditional uses of various parts from the eastern white pine (P. strobus).

Table 4. Traditional uses of various parts of eastern white pine, Pinus strobus (Adapted from Arnason et al., 1981)

\begin{tabular}{|c|c|c|}
\hline Part of the tree & Method & Traditional uses \\
\hline Needles & tea, infusion & $\begin{array}{l}\text { Treatment of flu-like symptoms, sore throat, skin problems, } \\
\text { fainting (physical and mental), scurvy. }\end{array}$ \\
\hline Twigs & tea, infusion & Lung problems, kidney disorders. \\
\hline Bark & tea, decoction & $\begin{array}{l}\text { Treatment of rheumatism, arthritis, menopausal symptoms, } \\
\text { breathing problems, inflammation }\end{array}$ \\
\hline Inner bark & as such & food \\
\hline
\end{tabular}

Data obtained from Moerman support the reputation of white pine as a remarkable source of medicines; the utilization of the various parts of this species remains far more extensive than for other Québec species (Moerman, 1986). Expanding the range of data previously available from Arnason, Moerman's paper describes 
dermatological uses (vs acne, pathogens) of the compounds extracted from sapwood and also the anti-inflammatory activity of these extracts (to treat deep cuts for instance). Moerman also mentions that decoctions of white pine leaves were integrated in pediatric medicine for children under the age of 3 .

\subsubsection{Current Knowledge on Pinus Extractives and Their Biological Properties}

Ethnopharmacological data available on native pine species from Québec forests suggest a strong potential for product development using extracts for therapeutic, cosmetic and nutraceutical purposes. Bark from these conifers - candidates for "tree of life" designation - are known for their applications in traditional medicine which serve as guidelines leading to the discovery of novel natural therapeutic agents.

Available information about Canadian pine extractives dates back to the 1960's, particularly for Jack pine bark ( $P$. banksiana). Benzenic extraction of Jack pine bark yielded up to $4.2 \%$ lipophilic extractives on a dry bark basis (Bower \& Rowe, 1967). The series of isolated compounds described in that research belong to acidic wax constituents, fatty acids, resin acids and polyphenols; the authors also highlighted the presence of $\beta$-sitosterol and dihydrosterol. Alone or in combination with other phytosterols, $\beta$-sitosterol reduces the level of blood cholesterol by inhibiting its absorption from the intestine. Bower and Rowe identified for the first time, labdanediterpenes such as the (+)-13-epimanoyl oxide but also identified torulosol and its derivatives, and triterpenes derived from serratenediol. More recent studies conducted on bark extracts from other species (genus Picea and Thuja) revealed that the oxide of (+)-13-epimanoyl exhibits antitumor properties (Iwamoto, Minami, Tokuda, Ohtsu, \& Tanaka, 2003; Kinouchi et al., 2000). Other terpenoids such as torulosol and its derivatives have been identified in extracts that show antifungal activity (Meneses, Durango, \& García, 2009). The presence of some hydrophobic polyphenols such as 3-5, dimethoxy-trans-stilbene (dimethyl-trans-pinosylvinether) and 3,5-dimethoxy-cis-stilbene (dimethyl-cis-pinosylvinether) was confirmed in Jack pine benzenic extract (Rowe, Bower, \& Wagner, 1969). These stilbenes and other polyphenols such as pinosylvin, pinobanksin, and (-)-norachelogenin were also detected in a methanolic extract from red pine wood ( $P$. resinosa); the cytotoxic activity and especially the selective effect of that extract on cancerous lung cells have been demonstrated (Simard, Legault, Lavoie, Mshvildadze, \& Pichette, 2008). It is noteworthy that polyphenols such as pinosylvin, its monomethyl ether derivative as well as the two flavones (-)-pinocembrin and (+)-pinobanksinhave been identified in nearly all pine wood species (Norin, 1972). While the composition of wood is recognized as very different from that of bark, some compounds can indeed be found simultaneously in several tissues. A study on white pine bark ( $P$. strobus) has confirmed the presence of several stilbenoids biosynthesized by the tree, as protective agents against attacks by pathogens such as nematodes or roundworms (Hanawa, Yamada, \& Nakashima, 2001). These bioactive polyphenols are hence called phytoalexins. The research work by Hanawa et al (2001) identified at least two such antifungal compounds: 3-O-dimethyl-dihydropinosylvin and (2S)-pinocembrin. The same authors stated that these are mainly present in the bark, and at lower concentrations in the wood tissue. Several studies have investigated the mode of action of phenolic compounds from different parts of trees, as agents against invasion by insects or microorganisms. In 1997, Beninger et al. provided analytical proof that red and white pine needles contained several phenolic compounds belonging to the class of flavonols (Table 5 ) which are known to counter the invasion by early gypsy moth instars (Lymantria dispar L.) (Beninger \& Abou-Zaid, 1997).

Table 5. Flavonol glycoside composition of ethanolic needle extracts from four pine species (Adapted from Beninger et al., 1997)

\begin{tabular}{llllll}
\hline \multirow{2}{*}{ Flavonol } & Jine species & & \\
& Jack & Red & Scots & White \\
\hline Kaempferol 3- $O$-glucoside & + & - & - & - \\
Kaempferol 3- $O$-galactoside & + & - & - & - \\
Kaempferol 3- $O$ - $p$-coumaroylglucoside & + & - & - & - \\
Quercetin 3- $O$-glucoside & + & + & + & + \\
Quercetin 3- $O$-galactoside & + & - & - & - \\
Quercetin 3- $O-p$-coumaroylglucoside & + & - & - & - \\
Quercetin 3- $O$-rutinoside & + & + & + & + \\
6- Methylkaempferol-3-glucoside & + & + & + & - \\
\hline
\end{tabular}

+: Positive Presence -: Not Detected. 
Bark or wood extractives from Scots pine (P. sylvestris) have been the subject of several studies. Bark extracts contain polyphenols that include proanthocyanidins (condensed tannins), catechin derivatives, glycosylated stilbenoids and flavonoids (Pan \& Lundgren, 1996). A paper published in 2004 describes the nature of polyphenols extracted with acetone (Table 6) and also highlights their remarkable anti-inflammatory activity (Karonen et al., 2004). Although rarely studied, pine roots were subjected to controlled extraction and the resulting material showed noticeable anticancer activity (Bradette \& Hébert, 2008).

Table 6. Polyphenolic compounds identified in the Scots pine (Pinus sylvestris) bark extract

\begin{tabular}{l}
\hline List of polyphenols identified by Karonen et al. 2004 \\
\hline taxifolin \\
taxifolin \\
p-hydroxybenzoicacid glucoside \\
procyanidintrimer \\
vanillicacid glucoside \\
catechin glucoside \\
procyanidin dimer \\
catechin derivatives \\
catechin \\
procyanidintrimer \\
$\beta$-hydroxypropiovanillone glucoside \\
ferulicacid glucoside \\
procyanidintrimer \\
epicatechin \\
procyanidin dimer \\
lignan glucoside \\
procyanidin tetramer \\
procyanidintrimer \\
lignanxyloside \\
\hline
\end{tabular}

The antioxidant activity of pine bark extracts has been highlighted for some time, particularly standardized French maritime pine bark extract ( $P$. pinaster) which is marketed under the trade names Pycnogenol ${ }^{\circledR}$ or Oligopin ${ }^{\circledR}$ (Packer, Rimbach, \& Virgili, 1999), (Tourino et al., 2005). This commercial extract is a mixture of flavonoids, mainly phenolic acids and procyanidins, and has a demonstrated capacity for scavenging free radicals generated by somatic cells under oxidative stress (caused by phenomena as varied as aging, pollution, alcohol, tobacco, exposure to UV light or various chemicals, etc.); those free radicals are known to be involved in degenerative diseases such as Alzheimer's, cardiovascular disease, arthritis and certain forms of cancer. $P$. pinaster bark extract is often used as benchmark when screening for antioxidant activities of new natural extracts. Reports are available on more than 730 formulations that include this extract as ingredient either of nutraceuticals or of cosmetics.

Recent comprehensive data describing the nature of extractives from the bark of native Québec pine species remain rare and therefore highlights the need to expand scientific investigations to screen and identification bioactive agents in bark. Data are available pertaining to the chemical composition and antioxidant properties of hydrophilic extracts from wood knots (Stevanovic, Diouf, \& Garcia-Perez, 2009; Yeşilada et al., 1995); reported extraction yields reached $6.8 \%$ for red pine knots and $19 \%$ for those of white pine. In a recent study, Jack pine knot extracts were shown to inhibit oxidative processes in human cells (Phelan, Aherne, Wong, \& O'Brien, 2009). 


\subsubsection{Pine Essential Oils}

Essential oil from pine species is widely known and in particular that of Scots pine (P. sylvestris) (Chalchat, Garry, Michet, \& Remery, 1985; Lazutka, Mierauskien, Slapšyt, \& Dedonyt, 2001; Kupcinskiene, Stikliene, \& Judzentiene, 2008). Compounds present in pine essential oil shave shown powerful antiseptic activity against respiratory, urinary and liver infections, with some acting as stimulants of the adrenal glands (Edris, 2007). The composition of the oil extracted from the needles of white, red and gray pines indicates the presence of terpenes such as $\beta$-pinene, $\alpha$-pinene and germacrene (Krauze-Baranowska, Mardarowicz, Wiwart, Pobłocka, \& Dynowska, 2002). These oils also exhibit antimicrobial activity (More, 2007).

\subsubsection{Results Obtained by Our Research Group on Pine Extractives and Their Biological Properties}

Studies on pine extractives conducted by our research group have focused on P. banksiana (Jack pine). The initial bioactivity screening was performed to evaluate in vitro antioxidant, anti-inflammatory and enzyme inhibitory activities of aqueous and ethanolic bark extracts from boreal species. Results showed that Jack pine bark contains high levels of extractives which can be easily prepared using hot water extraction (yield over 34\%) (Table 7) (García-Pérez et al., 2010) whereas ethanolic extraction proved less effective. Compared with standardized bark extract from maritime pine ( $P$. pinaster), the ethanolic Jack pine bark extract contains half the total phenol amount. Despite its high yield, the aqueous extract from Jack pine bark has the lowest content of total phenols among all other species studied by the authors. This suggests the possible presence of compounds other than polyphenols. Results reported in Table 8 indicate an absence of antioxidant activity in Jack pine aqueous bark extract when compared with that obtained by maceration in ethanol. The same research confirmed that the bark ethanolic extract has higher activity than Oligopin ${ }^{\circledR}$ (commercial maritime pine bark extract) against the free radical $\mathrm{NO}$, a reactive species involved in the inflammatory process.

Table 7. Results from Garcia-Pérez et al. (2010) presenting the yields of extractives obtained from barks of several wood species by two extraction methods

\begin{tabular}{|c|c|c|c|c|c|}
\hline Extracts & Yields (\%)* & 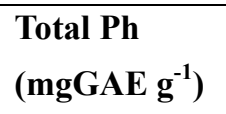 & 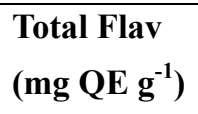 & $\begin{array}{l}\text { Total CinnAc } \\
\left(\operatorname{mg} \operatorname{ChAE~} \mathrm{g}^{-1}\right)\end{array}$ & $\begin{array}{l}\text { Pas content } \\
\left(\mathrm{mg} C \operatorname{chE} \mathrm{g}_{-}{ }^{1}\right)\end{array}$ \\
\hline YB ${ }_{\text {Mac }}$ & $9,29 \pm 0,72$ & $314,98 \pm 7,83^{\mathrm{c}}$ & $17,14 \pm 1,51^{\mathrm{d}}$ & $140,40 \pm 3,13^{b}$ & $43,04 \pm 5,62^{b}$ \\
\hline $\mathbf{Y B}_{\mathrm{HW}}$ & $6,99 \pm 0,89$ & $309,07 \pm 8,55^{\mathrm{c}}$ & $3,35 \pm 0,08^{\mathrm{g}}$ & $121,94 \pm 2,28^{\mathrm{d}}$ & $29,95 \pm 0,71^{\mathrm{c}}$ \\
\hline $\mathbf{B F}_{M a c}$ & $13,48 \pm 0,35$ & $182,08 \pm 7,69^{\mathrm{e}}$ & $19,06 \pm 0,17^{\mathrm{c}}$ & $82,98 \pm 1,92^{\mathrm{g}}$ & $12,89 \pm 1,17^{\mathrm{d}}$ \\
\hline $\mathbf{B F}_{\mathrm{HW}}$ & $28,87 \pm 3,47$ & $44,01 \pm 0,34^{\mathrm{f}}$ & $8,60 \pm 0,80^{f}$ & $58,89 \pm 1,77^{\mathrm{h}}$ & $4,33 \pm 0,21^{\mathrm{e}}$ \\
\hline $\mathbf{J P} \mathbf{M a c}_{\mathrm{Ma}}$ & $6,97 \pm 0,28$ & $232,58 \pm 2,36^{\mathrm{d}}$ & $39,87 \pm 0,57^{\mathrm{b}}$ & $106,76 \pm 3,05^{\mathrm{e}}$ & $17,08 \pm 1,36^{\mathrm{d}}$ \\
\hline $\mathbf{J P}_{\mathrm{HW}}$ & $34,21 \pm 1,37$ & $30,75 \pm 0,48^{\mathrm{g}}$ & $10,66 \pm 0,46^{\mathrm{e}}$ & $54,2 \pm 0,49^{\mathrm{i}}$ & $4,58 \pm 0,16^{\mathrm{e}}$ \\
\hline $\mathbf{B S}_{\mathrm{Mac}}$ & $5,25 \pm 0,54$ & $193,06 \pm 4,21^{\mathrm{e}}$ & $16,05 \pm 0,17^{\mathrm{d}}$ & $129,63 \pm 3,67^{\mathrm{c}}$ & $13,73 \pm 0,50^{\mathrm{d}}$ \\
\hline $\mathbf{B S}_{\mathrm{HW}}$ & $9,96 \pm 0,08$ & $404,29 \pm 4,04^{\mathrm{b}}$ & $53,40 \pm 1,05^{\mathrm{a}}$ & $90,28 \pm 0,92^{\mathrm{f}}$ & $11,78 \pm 0,11^{\mathrm{d}}$ \\
\hline Oligopin ${ }^{\circledR}$ & - & $572,92 \pm 12,07^{\mathrm{a}}$ & $7,43 \pm 0,09^{\mathrm{f}}$ & $335,49 \pm 3,36^{\mathrm{a}}$ & $104,97 \pm 9,59^{\mathrm{a}}$ \\
\hline
\end{tabular}

( $\mathrm{Mac}=$ maceration, $\mathrm{HW}=$ hot water). Total phenolic contents are listed as: (Total Ph), flavonoids (Total Flav), cinnamic acids (Total CinnAc) and proanthocyanidins (Pas).

YB: Yellow birch; BF: Balsam fir; JP: Jack pine; BS: Black spruce.

GAE: gallic acid equivalents; QE: quercetin equivalents; ChAE: chlorogenic acid equivalents; CchE: cyanidin chloride equivalents. 
Table 8. Results from Garcia-Pérez et al. (2010) showing concentrations (CN50) of extracts required to inhibit $50 \%$ of the oxidation caused by different reactive species released during oxidative stress. Data presented for several aqueous and ethanolic bark extracts from various Canadian species including Jack pine (JP in the Table)

\begin{tabular}{|c|c|c|c|c|c|}
\hline Extracts & $\begin{array}{l}\mathrm{H}_{2} \mathrm{O}_{2} \\
\text { CN50 }(\mu \mathrm{g} / \mathrm{ml})\end{array}$ & $\begin{array}{l}\mathrm{O}_{2}^{-} \\
\text {CN50 }(\mu \mathrm{g} / \mathrm{ml})\end{array}$ & $\begin{array}{l}\text { OH· } \\
\text { CN50 }(\mu \mathrm{g} / \mathrm{ml})\end{array}$ & $\begin{array}{l}\text { NO• } \\
\text { CN50 }(\mu \mathrm{g} / \mathrm{ml})\end{array}$ & $\begin{array}{l}\text { ROO· } \\
\text { CN50 }(\mu \mathrm{g} / \mathrm{ml})\end{array}$ \\
\hline YB $\mathbf{M a c}_{\text {Mc }}$ & $69,47 \pm 1,36^{\mathrm{e}}$ & $238,30 \pm 4,13^{\mathrm{e}}$ & $406,93 \pm 0,55 \mathrm{~g}$ & $1505,66 \pm 265,25^{\mathrm{b}}$ & $914,42 \pm 8,81^{\mathrm{c}}$ \\
\hline $\mathbf{Y B}_{\mathrm{HW}}$ & $68,45 \pm 0,39^{\mathrm{e}}$ & $296,30 \pm 5,67^{\mathrm{d}}$ & $858,85 \pm 0,94^{\mathrm{b}}$ & $1127,66 \pm 218,87^{\mathrm{c}, \mathrm{d}}$ & Not active \\
\hline$B F_{M a c}$ & $102,67 \pm 1,13^{\mathrm{b}}$ & $962,80 \pm 3,12^{\mathrm{a}}$ & $917,58 \pm 2,96^{\mathrm{a}}$ & Not active & $933,15 \pm 9,76^{\mathrm{b}}$ \\
\hline $\mathrm{BF}_{\mathrm{HW}}$ & $93,25 \pm 0,98^{\mathrm{c}}$ & $812,36 \pm 6,73^{b}$ & Not active & Not active & Not active \\
\hline $\mathbf{J P}_{\text {Mac }}$ & $72,05 \pm 0,96^{\mathrm{d}}$ & $773,96 \pm 2,63^{\mathrm{c}}$ & $645,49 \pm 1,17^{\mathrm{e}}$ & $889,33 \pm 151,06^{\mathrm{d}}$ & Not active \\
\hline $\mathbf{J P}_{\text {HW }}$ & Not active & Not active & Not active & Not active & Not active \\
\hline $\mathbf{B S}_{\text {Mac }}$ & $119,87 \pm 0,77^{\mathrm{a}}$ & $764,04 \pm 2,18^{\mathrm{c}}$ & $690,82 \pm 0,28^{\mathrm{d}}$ & $1475,66 \pm 48,41^{\mathrm{b}}$ & $780,17 \pm 1,21^{\mathrm{d}}$ \\
\hline BS $_{\mathrm{HW}}$ & $48,30 \pm 0,80^{\mathrm{f}}$ & $107,4 \pm 1,73^{\mathrm{f}}$ & $694,04 \pm 0,44^{\mathrm{c}}$ & $1352,66 \pm 156,07^{b, c}$ & $1116,77 \pm 7,71^{\mathrm{a}}$ \\
\hline Oligopin $^{\circledR}$ & $28,19 \pm 0,80^{\mathrm{g}}$ & $61,13 \pm 1,86^{\mathrm{g}}$ & $622,99 \pm 0,17 f$ & $2083,33 \pm 196,29^{\mathrm{a}}$ & $452,23 \pm 1,60^{\mathrm{e}}$ \\
\hline
\end{tabular}

YB: Yellow birch; BF: Balsam fir; JP: Jack pine; BS : Black spruce

Means with different letters in the same column are significantly different at $p<0.05$ (ANOVA, followed by Duncan test)

$\dagger \mathrm{IC}_{50}>500 \mu \mathrm{g} / \mathrm{ml}$.

$* \mathrm{IC}_{50}>2000 \mu \mathrm{g} / \mathrm{ml}$.

$\$ \mathrm{IC}_{50}>3000 \mu \mathrm{g} / \mathrm{ml}$.

$\mathrm{H}_{2} \mathrm{O}_{2}$ = Hydrogen peroxide radical scavenging activity.

$\mathrm{O}_{2}{ }^{--}=$Superoxide anion radical scavenging activity.

$\mathrm{OH}^{\bullet}=$ Hydroxyl radical scavenging activity.

$\mathrm{NO}^{\bullet}=$ Nitric oxide-radical scavenging activity.

\subsection{Larch: Genus Larix}

\subsubsection{The Various Species Found in Canada}

A total of seven species within the genus Larix have been catalogued in Canada, including three deemed indigenous (western larch, subalpine larch and tamarack). European larch was initially introduced but has since become fully naturalized in Canadian forests.

- $\quad$ Alpine larch (L. lyallii)

- $\quad$ Dahurian larch (L. gmelinii)

- $\quad$ European larch (L. decidua) Red larch (L. kaempferi)

- $\quad$ Siberian larch (L. sibirica)

- Western larch (L. occidentalis)

- White larch (L. laricina)

Within the Québec territory, only white larch (L. laricina) can be naturally found and its distribution pattern covers the whole Québec area below its Nordic limit. Among indigenous conifers, this species is alone in shedding its needles in winter, whereby in the fall its foliage changes color and drops. In fact, a good number of Québec citizens wrongly use the term "red spruce" in reference to this species; apparently this misnomer has its origins with the early colonists being from northwestern France and thus not familiar with conifer identification. White larch grows over most of Canada, essentially in wet areas and in association with black spruce, balsam fir, aspen and birch. This in fact hinders its harvesting and industrial transformation.

\subsubsection{Current Uses of White Larch (Larix laricina) by the Forest Industry}

This species retains a relative economic importance and finds various applications thanks to its strong and durable characteristics, especially for structures in contact with water and also as fuel for energy. Porcupines use the tree for shelter and as food source. Highly resistant to rot, white larch are highly sought for exterior uses, not 
only as shingles but also in deck construction. Its fine appearance and excellent quality (coupled with varying hues and patterns observed between the clear spring timber and the darker summer timber) yield strikingly beautiful furniture and finishing lumber. Manufacturing of paper pulp with larch fiber may be possible, however the terrain where this species often grows would make it challenging to machinery. As for its potential use as framing lumber, it dries at a much slower rate than spruce or fir. Overall, its remarkable hardness and durability remain attractive characteristics. In the past, it was often set aside for building large numbers of bridges over brooks and also for assembling warves; those applications were dependent on its dimensional stability.

\subsubsection{Larix Traditional Uses}

North American natives were the first to develop recorded uses for larch. For instance, they found ways to stitch their canoe bark using the roots, and had ways to dry and grind resin and bark to prepare baking powder or medicinal products to treat lung and kidney problems, ulcers and even to dress burns (Arnason et al., 1981). With regards to burn wounds, Ojibwa were known to use inner bark material to apply on the skin. In First Nations herbal medicine, other applications for larch included treatment against flu and colds, anemia, as laxative or kidney tonic, as wound disinfectant, painkiller, antipyretic, stimulant and expectorant. Natives had perfected techniques to make pillows and mattresses with its soft needles. The species also yields a sweet, edible gum.

\subsubsection{Current Knowledge on Larix Extractives and Their Biological Properties}

Literature reviews bring to light a general lack of studies on extractives from this species. Whatever work has been published deals mainly with the European larch (L. decidua).

White larch leaves (L. laricina) were first extracted in 1969 and the resulting compositional profile determined (Niemann, 1969). The author identified a series of glycosylated (carbohydrate-bearing) phenolic compounds derived from vanillic and $p$-coumaric acids in ethanolic leaves extract. A subsequent study pointed to the presence of other phenolic compounds in the leaves, namely acetylated flavonol glycosides(Niemann \& Bekooy, 1971).

More recently, a number of investigations have focused on leaves and twigs, and especially their essential oil. The latter's profile in terms of monoterpenes, sesquiterpenes and diterpenes (volatile compounds) after steam distillation was studied in three indigenous species (white, western and subalpine) (von Rudloff, 1987) and twigs were shown to yield higher amounts of essential oil than the leaves. This ranged from $1.1 \%$ in the case of white larch, up to $3 \%$ for the subalpine species; meanwhile yields from leaves averaged only $0.3 \%$. An ulterior study on the hydro distilled oil from leaves of white larch hybridized with other species, identified no less than 38 monoterpenic volatile compounds (Holm \& Hiltunen, 1997). The compositional variability of the same oil - with respect to volatile components - as influenced by seasonality, specimen and geographical site has been proposed as part of the defense mechanism of larch against various pests (Powell \& Raffa, 1999).

Analytical data on terpenes present in white larch bark extracts became recently available, and revealed four novel molecules: two novel diterpenic labdanes, a stilbenoid and a labdane known elsewhere but never previously identified in this species. This work focused mainly on dichloromethane extracts from branch bark, and this solvent yields lipophilic compounds; the same authors stated that their work was the first of its kind on larch bark extracts (Pichette et al., 2006).

The use of certain plants by Cree First Nations to alleviate diabetes has prompted investigations on the potential mode of action of white larch components; it is now understood that polyphenolic antioxidant compounds possess the ability to inhibit enzymes implicated in blood glucose biosynthesis. For instance, the antioxidant activities of white larch bark extracts, among other plant sources, have been measured (Fraser et al., 2007; Harbilas et al., 2009): results clearly prove the ethanolic extract's free radical scavenging activity, along with a polyphenolic content of $130 \mu \mathrm{g} / \mathrm{mg}$ of extract (as tannic acid equivalent). This activity was found to be superior to that of other compounds, such as ascorbic acid or Vitamin C, Trolox ${ }^{\circledR}$ (Vitamin E derivative) and three pure flavonoid antioxidants (catechin, epicatechin and quercetin).

\subsection{Fir: Genus Abies}

\subsubsection{The Various Fir Species Found in Canada}

A total of eight fir species have been identified in Canada, including three indigenous ones (balsam, giant, alpine); all others were introduced.

- $\quad$ Alpine fir (A. lasiocarpa)

- $\quad$ Balsam fir (A. balsamea) 


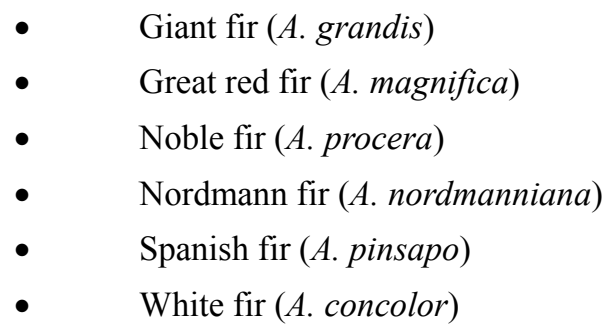

Québec forests harbor mainly balsam fir, which can be found in the various zones; this fir represents one of the most important species of the boreal forest and dominates in the white birch domain. One will notice balsam fir in hardwood forests as well, notably sugar bush.

\subsubsection{Common Uses of Abies by the Forest Industry}

Light, soft, coarse grained and rather whitish, this wood is used as saw lumber and also in pulp \& paper; minor applications include manufacturing musical instruments. Healthy balsam fir is sought for its uniform, clear hue. Its microstructural characteristics enhance the absorption of preservatives during the production of treated lumber. Those lumber cuts featuring minimal number of knots-also called clear wood-remain in high demand for specific applications. Certain properties make balsam fir a substitute for white pine, for instance in the manufacturing of furniture and windows and doors (Jobin, 2005).

\subsubsection{Abies Traditional Uses}

Balsam fir's designation (A. balsamea) refers to its strong fragrant character, specifically its resin-gum known and marketed around the world as "balsam Canada". Balsam fir gum is now recognized by Health Canada as a traditional herbal medicine, cleared for cases of respiratory tract infection and inflammation (SAPINO). Fir gum still enjoys a certain degree of popularity among French-Canadians as antiseptic poultice on wounds. This gum also yields various medicinal preparations, namely turpentine and turpentine oil. Known for its stimulatory effects, the former becomes a laxative at high doses, and exerts its action on the urinary system and respiratory tract mucosae ("Balsam Fir"). Turpentine enjoyed widespread use in earlier days, either as ointment or plasters, on cuts, on tissues affected by rheumatism, for lower back pain, etc. Turpentine oil, on the other hand, is obtained by distilling turpentine and thus differs from fir essential oil that derives from needles; the former has been recommended as stimulant, diuretic, wormicidal, rubefacient, mild perspirant, and in high doses, as laxative. Other applications that have been recorded include typhoid fever, cholera-associated diarrhea, child bed fever (as abdominal plaster), acute and chronic bronchitis, vaginal or bladder inflammation, chronic rheumatism and lumbago. Ethnopharmacological data collected by Arnason also indicate that Iroquois First Nations used the gum against cancer (Arnason et al., 1981), not to mention as a simple chewing treat.

North American Natives from coast to coast have cooked the internal bark from any of the four Canadian indigenous fir species. Ojibwas and Micmacs prepared bark decoctions to treat excess perspiration. The external bark and needle tea on the other hand were recommended as laxatives, whereas Montagnais were known to prepare infusions from collected twigs.

\subsubsection{Current Knowledge on Abies Extractives and Their Biological Properties}

A review of the literature on this species reveals much research since the 1950's, most of which dealing with the chemical analysis of various tissues on the premises of the various Abies known therapeutic applications. Most identified extractives obtained from balsam fir are classified as terpenes.

Early studies focused on the oleoresin known at the time as "balsam canada" exsudate, which contains 16 to $20 \%$ of hydrodistillable substances as components of the oil. The latter is comprised of monoterpenes such as $\alpha$-pinene and $\beta$-pinene, $\beta$-phellandrene and bornyl acetate (Anderson, 1955) as well as a diterpene designated as abienol (Gray \& Mills, 1964). Dedicated channels secrete the oleoresin under the bark. The main identified terpenic acids include abietic, neoabietic and palustric acids. Considered an important industrial material, abietic acid is used in varnishes and drying agents, in synthetic rubbers and for paper glues. This substance represents 35 to $45 \%$ of all commercial resins. Interestingly, abietic acid perse is not considered allergenic, however one of its auto-oxidation products (15-hydroperoxyabietic acid) happens to be one of the most powerful known natural allergens and interacts with cutaneous proteins. Another study published in 1974 on oleoresin composition revealed a series of additional monoterpenes: limonene, 3-carene, myrcene and camphene, besides certain oxygenated derivatives, namely linalool (molecule responsible for the fragrance of rosewood), $\alpha$-geraniol and terpineol (Chung, Snajberk, \& Zavarin, 1974). The essential oil recovered by hydrodistillation of the oleoresin yielded no less than 12 volatile sesquiterpenes (Thor \& Barnett, 1974). 
In parallel to those investigations on the oleoresin, a few studies focused on fir needle oil composition. Smirnoff in 1972 identified several volatile terpenes in needles: $\alpha$-and $\beta$-pinenes, limonene (beetle repellent), phellandrene, fenchone and $\alpha$ - and $\beta$-thujones; the authors also confirmed the respective antibacterial activity of those terpenes towards a number of pathogenic strains (Smirnoff, 1972). Thujones have a pleasant minty odor but become toxic in high amounts $(>45 \mathrm{mg} / \mathrm{kg})$ as they interact with brain neurons and may cause muscular spasms and convulsions. Nevertheless, low doses have been cleared for therapeutic use, as these compounds do show some positive activity on the immune defense system.

Most extractives isolated in the years 1950-1990 were obtained by steam (hydro) distillation. In 1997 a novel extraction method was proposed, macerating the tissues in the powerful lipophilic solvent dichloromethane (Bowman et al., 1997). These authors confirmed that the molecules identified by gas chromatography and mass spectrometry were identical to those previously noted in the essential oil obtained by hydrodistillation from the needles (Table 9). Other investigators determined the wax composition of the needles in an effort to better understand why certain insect larvae show a preference for this particular part of the tree (palatability effect) (Tulloch, 1987); a series of diterpenic acids and esters were thus identified. The resistance of balsam fir to exotic pests, as mediated by those terpenic compounds from the needles, has spurred further research on dichloromethane extracts (Carlow et al., 2006).

Table 9. Terpenic composition of the dichloromethane extract from balsam fir needles (Bowman et al., 1997)

\begin{tabular}{lll}
\hline Terpenes & \multicolumn{2}{l}{ Balsam fir needle extract } \\
& Mass, $\mathbf{~ m g / g}$ & RSD, $\mathbf{~}$ \\
\hline Tricyclene & 0.38 & 9 \\
$\alpha$-Pinene & 3.29 & 6 \\
Camphene & 3.26 & 6 \\
$\beta$-Pinene & 11.09 & 8 \\
3-Carene & 8.37 & 4 \\
Myrcene & 0.76 & 3 \\
Limonene & 2.81 & 6 \\
$\beta$-Phellandrene & 1.99 & 6 \\
$\gamma$-Terpinene & 0.09 & 16 \\
Cineole (internal standard) & - & - \\
$p$-Cymene & 0.05 & 9 \\
(Unknown) & 0.12 & 3 \\
$\beta$-Caryophyllene & 0.40 & 8 \\
Bornylacetate & 5.43 & 8 \\
$\beta$-Bisabolene & 0.76 & 7 \\
$\alpha$-Humulene & 0.18 & 31 \\
Borneol & 0.15 & 6 \\
Piperitone & 0.09 & 30 \\
(Unknown) & 6.44 & 11 \\
TOTAL & 46.08 & 5 \\
\hline
\end{tabular}

Work performed in 2003 by Legault et al. established that the essential oil steam-distilled from balsam fir needles is active against certain human cancerous cell lines; $\alpha$-humulene was singled out as the compound responsible for the bioactivity (Legault, Dahl, Debiton, Pichette, \& Madelmont, 2003). Other terpenic compounds isolated in the course of that study had been previously identified in the essential oil from branches (Simard, Hachey, \& Collin, 1988).

A study into the terpenic composition of the wood extracts confirmed the presence of the sesquiterpene juvabione and its derivatives, the latter already known for their protective activities against certain insects and 
pathogens in several conifers (John F. Manville \& Kriz, 1977). In 1998, Pichette et al. examined the compositional differences among hexane (lipophilic) extracts between woods from Jack pine, black spruce and balsam fir. Analytical data obtained by gas chromatography (GC) and mass spectrometry (MS) confirmed that juvabione, dehydrojuvabione and (E)- $\alpha$-atlantone (Table 10) are terpenes present strictly - and in significant amounts - in balsam fir wood (A. balsamea) (Pichette, Garneau, Jean, Riedl, \& Girard, 1998).

Table 10. Composition of hexanic extracts from balsam fir (Abies balsamea) heartwood (Pichette et al., 1998)

\begin{tabular}{lllll}
\hline Kovats Indices & Identification & Jack Pine & Black Spruce & BalsamFir \\
\hline 937 & $\alpha$-pinene & 64.75 & 12.99 & 0.31 \\
979 & $\beta$-pinene & 3.02 & 6.36 & 0.16 \\
1191 & $\alpha$-terpineol & 5.73 & 1.95 & 0.12 \\
1525 & 6-cadinene & 0.00 & 0.00 & 1.71 \\
1772 & (E)- $\alpha$-atlantone & 0.00 & 0.00 & 2.90 \\
1982 & manoyloxide & 0.81 & 1.40 & 0.18 \\
2002 & manoyloxide epi-13 & 1.08 & 2.41 & 0.00 \\
2017 & juvabione & 0.00 & 0.00 & 55.44 \\
2031 & unknown 1 & 0.63 & 9.10 & 0.00 \\
2053 & manool & 1.46 & 21.43 & 23.53 \\
2089 & dehydrojuvabione & 0.10 & 0.00 & 15.64 \\
2107 & isoabienol & 0.19 & 1.94 & 0.00 \\
2144 & neoabienol & 2.61 & 18.79 & 0.00 \\
2150 & (Z)-abienol & 3.99 & 1.43 & 0.00 \\
2158 & pimaranediterpene & 6.43 & 0.74 & 0.00 \\
2175 & unknown 2 & 2.77 & 0.87 & 0.00 \\
2189 & unknown 3 & 6.42 & 0.59 & 0.00 \\
\hline
\end{tabular}

In recent years, much attention has focused on extracts from balsam fir wood knots. Work carried out in 2003 confirmed that knot extracts from several species including balsam fir are notably rich in lignans, a class of polyphenolic compounds obtained during hydrophilic extraction (water, ethanol) (Holmbom et al., 2003). Best known among those from the genus Abiesis secoisolariciresinol, a potent natural antioxidant found in balsam knots alongside lariciresinol which has proven bioactivity against breast cancer (Saarinen et al., 2008). Knot extracts contain juvabione and sesquiterpenoïd acids as well (Figure 1).



Figure 1. Concentrations of extractives in knot wood hexane extracts obtained from four fir species (From Holmbom et al., 2003) 
Besides lignans, hydrophilic extracts from balsam fir knots also yield stilbenes and flavonoïds. Those extracts however do not exhibit any significant antibacterial activity when compared with those from other indigenous species (Valimaa et al., 2007).

Balsam fir bark has attracted very little attention. Spoor et al. (2006) investigated several species traditionally used by Cree First Nations to treat hyperglycemia (Spoor et al., 2006). The authors screened a series of polyphenolic extracts, looking for antidiabetic activity; their protocol consisted of extracting the inner bark tissue by macerating in ethanol; extraction yields reached $15.3 \%$ of the ground bark mass (dry basis). Analytical data pointed to a total phenolic content in the mid-range $(97 \mu \mathrm{g} / \mathrm{mg}$ of extract, as quercetin equivalent) compared with the other species studies. Inner bark extract from balsam fir therefore presents a rather average antidiabetic and antioxidant potential. Another report describes detectable fungicidal activity towards selected mould strains (Yang et al., 2004).

A review of work on extractives from balsam fir tissues confirms that terpenes found in steam-distilled oils are the compounds that have attracted most interest to date. There is an obvious lack of data on the nature of polyphenolic substances that can be isolated with hydrophilic solvents, especially those compounds present in the bark. Balsam fir extracts possess highly desirable biological activities, leading to applications in the medical domain (antitumoral, antimicrobial and fungicidal) and in cosmetics formulations just to mention a few.

\subsubsection{Results Obtained by Our Research Group on Fir Extractives and Their Biological Properties}

Aqueous and ethanolic extracts from balsam fir bark (A. balsamea) were screened in vitro by Garcia-Pérez et al. who also studied bark from other Canadian species that grow on the Québec territory (M.-E. García-Pérez et al., 2010). The authors concluded that hot water extraction afforded a higher yield ( $29 \%$ extractives, on a dry bark mass basis) compared with cold maceration in ethanol (13\% yield). On the other hand, the latter ethanolic extract may contain higher amounts of polyphenolics but its total phenol content is five-fold lower than that of standardized maritime pine extract $\left(\right.$ Oligopin $\left.^{\circledR}\right)$. The authors also investigated the free radical scavenging activity of various bark extracts against reactive oxygen species liberated during oxidative stress: the results obtained confirmed that hydrophilic extracts from balsam fir bark possess antioxidant/FRS activities that fall somewhere in the middle range when compared with other forest sources.

\section{Notes on Extractives From Minor Québec Softwoods}

As in our recent review on hardwood extractives (Royer et al., 2012), the present paper concludes with a general description of extractives already identified in minor species, extractives likely to find particular niche applications.

\subsection{Hemlock: Genus Tsuga}

Among the three species of hemlock indigenous to Canada, only Tsuga canadensis or eastern hemlock can be found on the Québec territory and is the least cold-tolerant species within the Pinaceae family. This tree grows in shady, humid, cool areas and generally in association with birch, beech or sugar maple. Hemlock wood has been described as light, soft, brittle, but stronger than white pine. Main uses include framing, boxes and cases, retaining walls, and pulp for paper. Leather tanneries are important users of hemlock bark, due to the latter's very high tannin content. First Nations traditions often mention eastern hemlock, referring to its astringent and antiseptic properties. Decoctions using the whole bark were recommended against diarrhea, cystitis, and colic. Iroquois First Nations had named this species' Annedaor «tree of life», and were known to prepare bark and needle tea against scurvy and venereal diseases (Arnason et al., 1981). Micmacs considered the internal bark edible, and also used it as plaster over wounds, in vaginal douches, and as gargle solution against throat aches and mouth inflammation (Foster \& Duke, 1990). Poultices prepared from the inner bark were efficacious against various skin disorders. To treat cases of dysentery, Ojibwas would make use of hemlock twigs.

Ethnopharmacological reports described the biological properties of the inner bark from eastern hemlock. Whereas tanneries were using the whole bark, curative properties were assigned to the inner bark (Garr \& Ewé, 1920). Table 11 found in the Garr and Ewé paper lists the extractive contents of selected bark fractions, for both aqueous and ethanolic extracts. 
Table 10. Yields of aqueous and ethanolic extracts from hemlock bark fractions (Garr \& Ewé, 1920).

\begin{tabular}{llcc}
\hline Lot No & Bark fraction & Hot water soluble extractives (\%) & 32\% ethanol soluble extractives (\%) \\
\hline 1 & Whole & 11.88 & 18.29 \\
& Outer & 11.27 & 18.20 \\
\multirow{2}{*}{2} & Inner & 13.37 & 18.52 \\
& Whole & 12.57 & 20.56 \\
& Outer & 12.54 & 21.36 \\
\multirow{3}{*}{3} & Inner & 12.60 & 19.60 \\
& Whole & 13.09 & - \\
& Outer & 12.75 & - \\
4 & Inner & 13.62 & - \\
& Whole & 11.27 & 18.72 \\
& Outer & 10.29 & 18.60 \\
\hline
\end{tabular}

No recent studies have been made available on the composition of eastern hemlock bark. A paper from 2003 does however present a highly comprehensive description of terpenic compounds found in needles (Lagalante \& Montgomery, 2003). Another confirms the presence of several flavonoids (polyphenols) in needles and in leaves (Feucht, Treutter, \& Polster, 2004).

\subsection{Cedar: Genus Thuja}

Of the two known indigenous cedars in Canada, eastern (northern) white cedar (Thuja occidentalis) and western red cedar (Thuja plicata), the former remains the major one found on the Québec territory. Cedar wood is known as light, fragrant, easy to split and resistant to rot. Hence, its specific applications in warf building, foundation work, beams, fences, telegraphic poles and shingles. The term "cedar" assigned to thuja is in fact incorrect: true cedars are altogether different, and don't belong in the Cupressaceae family. White cedar has been often cited in folk remedies and First Nations healing medicine: leaf tea was popular as a tonic, against headaches and coughs, not to mention its use in aromatherapy (inhalation of steam-volatilized compounds). Very little information can be retrieved with regards to the bark; Arnason briefly mentions that cedar bark was applied on burn wounds (Arnason et al., 1981). Various components present in extractives from this species include tannins, thujones, fenchone, camphor, terpinen-4-ol, and bornylacetate.

According to our review, several studies have focused on various extracts from cedars and their biological properties, with most data relating to white cedar. Phytochemical analysis on extracts from branches, xylem or foliage revealed the following series of compounds: (1) monoterpenes ( $\alpha$-thujone, $\beta$-thujone, fenchone), (2) diterpenes (dehydroabietane, neothujic III and IV acids), (3) the sesquiterpene (+)-occidentalol) (D. N. Roy, Konar, \& Purdy, 1984), (4) several lignans (8R,8'R)-(-)-matairesinol, (8R,8'R)-(-)-thujaplicatin methyl ether, (8S,8'S)-(-)-wikstromol, 8-hydroxy-thujaplicatin methyl ether and epi-pinoresinol, pinoresinol and secoisolariciresinol), along with several other compounds exhibiting antitumoral activities (Kawai, Sugishita, \& Ohashi, 1999). Methanolic extracts from foliage and cones demonstrated noticeable antibacterial activities (Ezzat, 2001). Interestingly, a 2005 review has described in detail the pharmacological potential of foliage essential oil (Naser, Bodinet, Tegtmeier, \& Lindequist, 2005) including detailed phytochemical analysis of the oil as well as data on the effect of extraction solvent type. Leaves yield $0.6 \%$ essential oil, with thujones as main constituents. Branches, twigs and other tissues contain those compounds as well. The authors state that extraction using $30 \%$ ethanol each yields $2.8 \mathrm{mg}$ thujones per gram of fresh leaves, and subsequently describe the various pharmacological properties of the extracts, followed by related clinical trials. Independently, extracts from western red cedar knot wood and from white cedar bark were subjected to antioxidant screening, since both types of extracts contain thuyaplicatine derivatives. The overall yield (using aqueous acetone as extraction solvent) of hydrophilic extractives was $5.9 \%$ for the bark, a major proportion being carbohydrates (Pietarinen et al., 2006) with stilbenes and tannins present as well. The authors concluded that knot wood extracts from western red cedar possess high free radical scavenging activity compared with similar extracts from white cedar, despite the latter being higher in thujalignans.

\section{Conclusions}

The present literature review on softwood extractives from Québec forest species-notably the commercialized 
ones-emphasizes the following points:

- A good number of phytochemical studies are available on those species with recognized nutraceutical, cosmeceutical or therapeutic properties. However there is a definite lack of information on the properties of extractives from North American species compared with those from corresponding European species.

- As for hardwood species, recorded ethnopharmacological data represent an essential tool when designing and implementing future research programs that focus on high-potential species.

- Conifers on the Québec territory should be viewed as significant sources of extractives demonstrating varied bioactivities. Bark extracts besides essential oils are high in polyphenols, with clearly demonstrated benefits. Those compounds have been shown to be present in substantial proportions in spruce bark extracts, and the latter exhibit significant antioxidant activities-comparable with, if not higher than Pycnogenol ${ }^{\circledR}$, a commercial maritime pine bark extract. Terpenes extracted from pine bark have been confirmed as anticholesterolemic and antitumoral, whereas their phenolic counterparts are largely responsible for the antimicrobial and especially the antioxidant activities in those extracts. Bark material from larch represents another remarkable source of highly antioxidant polyphenols.

In parallel with the status of hardwood extractives research, less work has been devoted to the bark of conifers relative to other parts (foliage, cones, branches ...) in terms of compositional characterization. Here again, a clear distinction is required between (i) essential oils from various tissues and (ii) polar extracts of segregated tissues for instance external and internal barks. Overall, there is a need to establish and conduct strategic R \& D programs that will lead to precise identification of key components in bark extractives and their unique biological properties. Only then will maximum scientific and commercial value be derived from this plentiful renewable resource.

\section{References}

Amusant, N. (2003). Durabilité naturelle et couleur des bois de Guyane: mesure, variabilité, déterminisme chimique. Applications à Dicorynia guianensis (Angélique), Sextonia rubra (Grignon), Eperua falcata (Wapa) et Eperua grandiflora (Wapa courbaril). Thèse. Ecole Nationale du Génie Rural, des Eaux et des Forêts, Guyane française.

Anderson, A. B. (1955). Recovery and utilization of tree extractives. Economic Botany, 9(2), 108-140. http://dx.doi.org/10.1007/BF02898793

Arnason, T., Hebda, R. J., \& Johns, T. (1981). Use of plants for food and medicine by Native Peoples of eastern Canada. Canadian Journal of Botany, 59, 2189-2325. http://dx.doi.org/10.1139/b81-287

Bairacli, L. (1997). Common Medicinal Herbs For Natural Health.Balsam Fir. Ash Tree Publishing, Woodstock, New-York.

Beaulieu, J., Girarda, B., \& Fortin, Y. (2002). Effect of drying treatments on warping of 36-year-old white spruce seed sources tested in a provenance trial. Paper presented at the Wood, Breeding, Biotechnology and Industrial Expectations Conference. Québec City, Canada.

Beninger, C. W., \& Abou-Zaid, M. M. (1997). Flavonol glycosides from four pine species that inhibit early instar gypsy moth (Lepidoptera: Lymantriidae) development. Biochemical Systematics and Ecology, 25(6), 505-512. http://dx.doi.org/10.1016/S0305-1978(97)00034-3

Bower, C. L., \& Rowe, J. W. (1967). Extractives of Jack pine bark: Occurrence of (+)-13-epimanoyl oxide and related labdane diterpenes. Phytochemistry, 6(1), 151-153. http://dx.doi.org/10.1016/0031-9422(67)85024-6

Bowman, J. M., Braxton, M. S., Churchill, M. A., Hellie, J. D., Starrett, S. J., Causby, G. Y., \& Butcher, D. J. (1997). Extraction Method for the Isolation of Terpenes from Plant Tissue and Subsequent Determination by Gas Chromatography. Microchemical Journal, 56(1), 10-18. http://dx.doi.org/10.1006/mchj.1996.1422

Bradette Hébert, M. E. (2008). Étude du potentiel biopharmaceutique du Solidago Canadensis Linné. In. M. D. Maîtrise (Ed.), Université du Québec à Chicoutimi, Chicoutimi, Canada.

Burchill, C. (2008). Jack pines in Manitoba Canoe country. Paddle Manitoba, Winnipeg, Canada.

Carlow, S. J., Ayers, L., Bailey, A., John, B., Richardson, A., Shepherd, B., \& Butcher, D. J. (2006). Determination of volatile compounds in foliage of Fraser fir (Abies fraseri) and balsam fir (Abies balsamea). Microchemical Journal, 83(2), 91-97. http://dx.doi.org/10.1016/j.microc.2006.03.003

Chalchat, J. C., Garry, R. P., Michet, A., \& Remery, A. (1985). The essential oils of two chemotypes of Pinus sylvestris. Phytochemistry, 24(10), 2443-2444. http://dx.doi.org/10.1016/S0031-9422(00)83062-9 
Chartier, C. (2009). Épinette rouge, de la tradition à l'utilisation actuelle. The red spruce: from traditional to contemporary uses. Phytothérapie, 7(5), 251-254. http://dx.doi.org/10.1007/s10298-009-0405-8.

Chung, J. L., Snajberk, K., \& Zavarin, E. (1974). Chemical composition of the cortical essential oil from Abies balsamea. Phytochemistry, 13(1), 179-183. http://dx.doi.org/10.1016/S0031-9422(00)91290-1

Daoust, G. (1999). Les programmes d'amélioration génétique :bilan des réalisations; l'épinette de Norvège. Paper presented at the seminar L'amélioration génétique en foresterie: où en sommes-nous? Rivière-du-Loup, Québec, Canada.

Diouf, P. N., Stevanovic, T., \& Cloutier, A. (2009). Study on chemical composition, antioxidant and anti-inflammatory activities of hot water extract from Picea mariana bark and its proanthocyanidin-rich fractions. Food Chemistry, 113(4), 897-902. http://dx.doi.org/10.1016/j.foodchem.2008.08.016

Durzan, D. J. (2009). Arginine, scurvy and Cartier's "tree of life". Journal of Ethnobiology and Ethnomedicine 5(I), 5. http://dx.doi.org/10.1186/1746-4269-5-5

Edris, A. E. (2007). Pharmaceutical and therapeutic potentials of essential oils and their individual volatile constituents: a review. Phytotherapy Research, 21(4), 308-323. http://dx.doi.org/10.1002/ptr.2072

Essential Oil Profile: Black Spruce. (2011). Retrieved from http://www.anandaapothecary.com/aromatherapy-essential-oils/black-spruce-oil.html.

Evensen, P. C., Solheim, H., Høiland, K., \& Stenersen, J. (2000). Induced resistance of Norway spruce, variation of phenolic compounds and their effects on fungal pathogens. Forest Pathology, 30(2), 97-108. http://dx.doi.org/10.1046/j.1439-0329.2000.00189.x

Ezzat, S. M. (2001). In vitro inhibition of Candida albicans growth by plant extracts and essential oils. World Journal of Microbiology and Biotechnology, 17(7), 757-759. http://dx.doi.org/10.1023/A:1012934423019

Fauconneau, B. Waffo-Teguo, P., Huguet, F., Barrier, L., Decendit, A., \& Merillon, J. M. (1997). Comparative study of radical scavenger and antioxidant properties of phenolic compounds from Vitis vinifera cell cultures using in vitro tests. Life Sciences, 61(21), 2103-2110. http://dx.doi.org/10.1016/S0024-3205(97)00883-7

Feucht, W., Treutter, D., \& Polster, J. (2004). Flavanol binding of nuclei from tree species. Plant Cell Reports, 22(6), 430-436. http://dx.doi.org/10.1007/s00299-003-0705-7

Foster, S., \& Duke, J. A. (1990). A field guide to medicinal plants and herbs of eastern and central North America. In H. M. Company (Ed.)

FPInnovations. (2000). Wood Characteristics, Processing and End Uses of Jack Pine. Québec: FPInnovations.

Fraser, M. H., Cuerrier, A., Haddad, P. S., Arnason, J. T., Owen, P. L. \& Johns, T. (2007). Medicinal plants of Cree communities (Québec, Canada): antioxidant activity of plants used to treat type 2 diabetes symptoms. This article is one of a selection of papers published in this special issue (part 2 of 2) on the Safety and Efficacy of Natural Health Products. Canadian Journal of Physiology and Pharmacology, 85(11), 1200-1214. http://dx.doi.org/10.1139/Y07-108

Friedland, A. J., Hawley, G. J., \& Gregory, R. A. (1988). Red spruce (Picea rubens Sarg.) foliar chemistry in Northern Vermont and New York, USA. Plant and Soil, 105(2), 189-193. http://dx.doi.org/10.1007/BF02376782

Frost,

$\mathrm{R}$.

Retrieved

from http://www.selfhealdistributing.com/pdf/sundew-moonwort-volume-2-sample-blackspruce.pdf

García-Pérez, M .E., Royer, M., Herbette, G., Desjardins, Y., Pouliot, R., \& Stevanovic, T. (2012). Picea mariana bark: a new source of trans-resveratrol and other bioactive polyphenols. Food Chemistry, 135(3), 1173-1182. http://dx.doi.org/10.1016/j.foodchem.2012.05.050

García-Pérez, M. E., Royer, M., Duque-Fernandez, A., Diouf, P. N., Stevanovic, T., \& Pouliot, R. (2010). Antioxidant, toxicological and antiproliferative properties of Canadian polyphenolic extracts on normal and psoriatic keratinocytes. Journal of Ethnopharmacology, 132(1), 251-258. http://dx.doi.org/10.1016/j.jep.2010.08.030

Garr, H. D., \& Ewé, G. E. (1920). Hemlock bark (Tsuga canadensis) for pharmaceutical purposes. Journal of the American Pharmaceutical Association, 9(6), 567-573. http://dx.doi.org/10.1002/jps.3080090606

Giguère, M. (2008). Le Pin gris ou Pinus banksiana. Paper presented at the seminar"L'utilisation des essences 
résineuses comme bois d'apparence", Université Laval, Québec.

Gray, P. S., \& Mills, J. S. (1964). The isolation of abienol from Canada Balsam, the oleoresin of Abies balsamea (L.) Mill. Journal of the Chemical Society (Resumed), 5822-5825. http://dx.doi.org/10.1039/jr9640005822

Hammerbacher, A. R., Steven, G., Bohlmann, J., Fenning, T. M., Gershenzon, J., \& Schmidt, A. (2011). Biosynthesis of the major tetrahydroxystilbenes in spruce, astringin and isorhapontin, proceeds via resveratrol and is enhanced by fungal infection. Plant Physiology, 157(2), 876-890. http://dx.doi.org/10.1104/pp.111.181420

Hanawa, F., Yamada, T., \& Nakashima, T. (2001). Phytoalexins from Pinus strobus bark infected with pinewood nematode, Bursaphelenchus xylophilus. Phytochemistry, $\quad$ 57(2), 223-228. http://dx.doi.org/10.1016/S0031-9422(00)00514-8

Harbilas, D., Martineau, L. C., Harris, C. S., Adeyiwola-Spoor, D. C. A., Saleem, A., Lambert, J., \& Haddad, P. S. (2009). Evaluation of the antidiabetic potential of selected medicinal plant extracts from the Canadian boreal forest used to treat symptoms of diabetes: part II. Canadian Journal of Physiology and Pharmacology, 87(6), 479-492. http://dx.doi.org/10.1139/Y09-029

Holm, Y., \& Hiltunen, R. (1997). Variation and inheritance of monoterpenes in Larix species. Flavour and Fragrance Journal, 335-339. http://dx.doi.org/10.1002/(SICI)1099-1026(199709/10)12:5<335::AID-FFJ664>3.3.CO;2-9

Holmbom, B., Eckerman, C., Eklund, P., Hemming, J., Nisula, L., Reunanen, M., \& Willför, S. (2003). Knots in trees-A new rich source of lignans. Phytochemistry Reviews, 2(3), 331-340. http://dx.doi.org/10.1023/B:PHYT.0000045493.95074.a8

Iwamoto, M., Minami, T., Tokuda, H., Ohtsu, H., \& Tanaka, R. (2003). Potential antitumor-promoting diterpenoids from the stem bark of Thuja standishii. Planta Med, 69(01), 69-72. http://dx.doi.org/10.1055/s-2003-37037

Jobin, B. (2005). Étude sur la seconde transformation du sapin baumier. Nord (Ed.). Québec.

Karonen, M., Hämäläinen, M., Nieminen, R., Klika, K. D., Loponen, J., Ovcharenko, V. V., \& Pihlaja, K. (2004). Phenolic Extractives from the bark of Pinus sylvestris L. and their effects on inflammatory mediators nitric oxide and prostaglandin E2. Journal of Agricultural and Food Chemistry, 52(25), 7532-7540. http://dx.doi.org/10.1021/jf048948q

Karst, A. (2010). Conservation value of the North American boreal forest from an ethnobotanical perspective. Canada: David Suzuki Foundation and the Boreal Songbird Initiative.

Kawai S., Sugishita, K., \& Ohashi, H. (1999). Identification of Thuja occidentalis lignans and its biosynthetic relationship. Phytochemistry, 51(2), 243-247. http://dx.doi.org/10.1016/S0031-9422(99)00004-7

Kersten, P. J., Kopper, B. J., Raffa, K. F. \& Illman, B. L. (2006). Rapid analysis of abietanes in conifers. Journal of Chemical Ecology, 32(12), 2679-2685. http://dx.doi.org/10.1007/s10886-006-9191-z

Kinouchi, Y., Ohtsu, H., Tokuda, H., Nishino, H., Matsunaga, S., \& Tanaka, R. (2000). Potential antitumor-promoting diterpenoids from the stem bark of Picea glehni. Journal of Natural Products, 63(6), 817-820. http://dx.doi.org/10.1021/np0000217

Kraus, C., \& Spiteller, G. (1997). Comparison of phenolic compounds from galls and shoots of Picea glauca. Phytochemistry, 44(1), 59-67. http://dx.doi.org/10.1016/S0031-9422(96)00388-3

Krauze-Baranowska, M., Mardarowicz, M., Wiwart M., Pobłocka, L., \& Dynowska, M. (2002). Antifungal activity of the essential oils from some species of the genus Pinus. Zeitschrift für Naturforschung, 57(5-6), 478-482.

Kuhlein, H. V., \& Turner, N. J. (1991). Nutrition, Botany and Use. Traditional plant foods of canadian indigenous peoples. Canada: Gordon and Breach. http://dx.doi.org/10.2307/2444923

Kupcinskiene, E., Stikliene, A., \& Judzentiene, A. (2008). The essential oil qualitative and quantitative composition in the needles of Pinus sylvestris L. growing along industrial transects. Environmental Pollution, 155(3), 481-491. http://dx.doi.org/10.1016/j.envpol.2008.02.001

Lagalante, A. F., \& Montgomery, M. E. (2003). Analysis of terpenoids from hemlock (Tsuga) species by solid-phase microextraction/gas chromatography/ion-trap mass spectrometry. Journal of Agricultural and Food Chemistry, 51(8), 2115-2120. http://dx.doi.org/10.1021/jf021028s 
Lazutka, J. R., Mierauskien, J., Slapšyt, G., \& Dedonyt, V. (2001). Genotoxicity of dill (Anethum graveolens L.), peppermint (Mentha $\times$ piperita L.) and pine (Pinus sylvestris L.) essential oils in human lymphocytes and Drosophila melanogaster. Food and Chemical Toxicology, 39(5), 485-492. http://dx.doi.org/10.1016/S0278-6915(00)00157-5

Legault, J., Dahl, W., Debiton, E., Pichette, A., \& Madelmont, J. C. (2003). Antitumor activity of balsam fir oil: production of reactive oxygen species induced by $\alpha$-humulene as possible mechanism of action. Planta Med, 69(05), 402,407.

Li, H. L., Wang, A. B., Huang, Y., Liu, D. P., Wei, C., Williams, G., ... \& Chih-Chuan. (2005). Isorhapontigenin, a new resveratrol analog, attenuates cardiac hypertrophy via blocking signaling transduction pathways. Free Radical Biology and Medicine, 38(2), 243-257. http://dx.doi.org/10.1016/j.freeradbiomed.2004.10.020

Li, S. H., Niu, X. M.i, Zahn, S., Gershenzon, J., Weston, J., \& Schneider, B. (2008). Diastereomeric stilbene glucoside dimers from the bark of Norway spruce (Picea abies). Phytochemistry, 69(3), 772-782. http://dx.doi.org/10.1016/j.phytochem.2007.08.033

Lindberg, L. E., Willför, S. M., \& Holmbom, B. R. (2004). Antibacterial effects of knotwood extractives on paper mill bacteria. Journal of Industrial Microbiology and Biotechnology, 31(3), 137-147. http://dx.doi.org/10.1007/s10295-004-0132-y

Madamanchi, N. R., Hausladen, A., Alscher, R. G., Amundson, R. G., \& Fellows, S. (1991). Seasonal changes in antioxidants in red spruce (Picea rubens Sarg.) from three field sites in the northeastern United States. New phytologist, 118(2). http://dx.doi.org/10.1111/j.1469-8137.1991.tb00985.x

Manners, G. D., \& Swan, E. P. (1971). Stilbenes in the barks of five canadian Picea species. Phytochemistry, 10(3), 607-610. http://dx.doi.org/10.1016/S0031-9422(00)94705-8

Manville, J. F., Nault, J. R., \& Sahota, T. S. (1999). Spruce terpenes: expression and weevil resistance. Canadian Journal of Forest Research, 29(6), 761. http://dx.doi.org/10.1139/x99-053

Manville, J. F., \& Kriz, C. D. (1977). Juvabione and its analogues.: IV. Isolation, identification, and occurrence of juvabione, juvabiol, and epijuvabiol from the whole wood of Abies lasiocarpa. Canadian Journal of Chemistry, 55(13), 2547-2553. http://dx.doi.org/10.1139/v77-351

McCune, L. M., \& Johns, T. (2002). Antioxidant activity in medicinal plants associated with the symptoms of diabetes mellitus used by the Indigenous Peoples of the North American boreal forest. Journal of Ethnopharmacology, 82(2-3), 197-205. http://dx.doi.org/10.1016/S0378-8741(02)00180-0.

Meneses, E. A., Durango, D. L., \& García, C. M. (2009). Antifungal activity against postharvest fungi by extracts from Colombian propolis. Química Nova, 32, 2011-2017. http://dx.doi.org/10.1590/S0100-40422009000800006

Mérillon, J. M., Fauconneau, B., Teguo, P. W., Barrier, L., Vercauteren, J., \& Huguet, F. (1997). Antioxidant activity of the stilbene astringin, newly extracted from Vitis viniferacell cultures. Clinical Chemistry, 43(6), 1092-1093.

Moerman, D. (Ed.). (1986). Medicinal Plants of Native America (Vol. 1 \& 2): University of Michigan Museum of Anthropology.

More, F. N. (2007). Antimicrobial properties of conifer essential oils: a summary I. C. REPORT (Ed.)

Mottet, M. J., \& Daoust, G. (2007). Pour du bois de qualité en plantation : l'épinette de Norvège demeure un bon choix! Seminar. Université Laval, Québec.

MRNF. (2008). La forêt pour construire le Québec de demain. Québec: MRNF.

Naser, B., Bodinet, C., Tegtmeier, M., \& Lindequist, U. (2005). Thuja occidentalis (Arbor vitae): areview of its pharmaceutical, pharmacological and clinical properties. Evidence-based Complementary and Alternative Medicine, 2(1), 69-78. http://dx.doi.org/10.1093/ecam/neh065

Niemann, G. J., \& Bekooy, R. (1971). Flavonoid constituents from Larix needles. Phytochemistry, 10(4). http://dx.doi.org/10.1016/S0031-9422(00)97163-2

Niemann, Gerard J. (1969). Phenolic glucosides from needles of Larix laricina. Phytochemistry, 8(10), 2101-2103. http://dx.doi.org/10.1016/S0031-9422(00)88104-2

Norin, T. (1972). Extractives from the bark of common spruce, Picea abies L. karst. Acta chemica scandinavica, 26(6). 
Packer, L., Rimbach, G., \& Virgili, F. (1999). Antioxidant activity and biologic properties of a procyanidin-rich extract from pine (Pinus maritima) bark, Pycnogenol. Free Radical Biology and Medicine, 27(5-6), 704-724. http://dx.doi.org/10.1016/S0891-5849(99)00090-8

Pan, Hefeng, \& Lundgren, L. N. (1995). Phenolic extractives from root bark of Picea abies. Phytochemistry, 39(6), 1423-1428. http://dx.doi.org/10.1016/0031-9422(95)00144-V

Pan, H., \& Lundgren, L. N. (1996). Phenolics from inner bark of Pinus sylvestris. Phytochemistry, 42(4), 1185-1189. http://dx.doi.org/10.1016/0031-9422(96)00122-7

Parent, B. (2009). Ressources et Industries forestières, Portrait statistique. MRNF. Québec.

Phelan, M. S., Aherne, A., Wong, A., \& O'Brien, N. M. (2009). Bioactive properties of wood knot extracts on cultured human cells. Journal of Medicinal Food, 12(6), 1245-1251. http://dx.doi.org/10.1089/jmf.2008.0125

Pichette, A., Garneau, F. X., Jean, F. I. , Riedl, B., \& Girard, M. (1998). Chemical differences between the wood extracts of Jack pine (Pinus banksiana), black spruce (Picea mariana) and balsam fir (Abies balsamea) from eastern Canada. Journal of wood chemistry and technology, 18(4). http://dx.doi.org/10.1080/02773819809349590

Pichette, A., Lavoie, S., Morin, P., Mshvildadze, V., Lebrun, M., \& Legault, J. (2006). New labdane diterpenes from the stem bark of Larix laricina. Chemical and Pharmaceutical Bulletin, 54(10), 1429-1432. http://dx.doi.org/10.1248/cpb.54.142

Pietarinen, S. P., Willför, S. M., Ahotupa, M. O., Hemming, J. E., \& Holmbom, B. R. (2006). Knotwood and bark extracts: strong antioxidants from waste materials. Journal of Wood Science, 52(5), 436-444. http://dx.doi.org/10.1007/s10086-005-0780-1

Powell, J. S., \& Raffa, K. F. (1999). Sources of variation in concentration and composition of foliar monoterpenes in tamarack Larix laricina seedlings: roles of nutrient availability, time of season, and plant architecture. Journal of Chemical Ecology, 25(8), 1771-1797. http://dx.doi.org/10.1023/A:1020973514476

Ritch-Krc, E. M., Turner, N. J., \& Towers, G. H. N. (1996). Carrier herbal medicine: an evaluation of the antimicrobial and anticancer activity in some frequently used remedies. Journal of Ethnopharmacology, 52(3), 151-156. http://dx.doi.org/10.1016/0378-8741(96)01407-9

Roger, I. H. (1967). Wood extractives : the structure and chemistry of some triterpenes isolated from the bark of Sitka spruce (Picea stichensis). (PhD), University of British Columbia. Retrieved from http://www.library.ubc.ca/archives/retro_theses

Rousseau, J. (1954). L'annedda et l'arbre de vie. Revue d'histoire de l'Amérique française, 8(2), 171-212. http://dx.doi.org/10.7202/301648ar

Rowe, J. W., Bower, C. L., \& Wagner, E. R. (1969). Extractives of Jack pine bark: Occurrence of cis- and trans-pinosylvin dimethyl ether and ferulic acid esters. Phytochemistry, 8(1), 235-241. http://dx.doi.org/10.1016/S0031-9422(00)85819-7

Roy, D. N., Konar, S. K., \& Purdy, J. R. (1984). Sublimation of occidentalol, a sesquiterpene alcohol, from eastern white cedar (Thuja occidentalis) in a drying kiln. Canadian journal of forest research 14(3), 401-403. http://dx.doi.org/10.1139/x84-071

Roy, J., \& Bergeron J. M. (1990). Role of phenolics of coniferous trees as deterrents against debarking behavior of meadow voles (Microtus pennsylvanicus). Journal of Chemical Ecology, 16(3), 801-808. http://dx.doi.org/10.1007/BF01016490

Royer, M., Houde, R., Viano, Y., \& Stevanovic, T. (2012). Non-wood forest products based on extractives - anew opportunity for the Canadian forest industry Part 1: Hardwood Forest Species. Journal of Food Research, 1(3). http://dx.doi.org/10.5539/jfr.v1n3p8

Rudloff, E. von. (1972). Seasonal variation in the composition of the volatile oil of the leaves, buds, and twigs of white spruce (Picea glauca). Canadian Journal of Botany, 50(7), 1595-1603. http://dx.doi.org/10.1139/b72-195

Saarinen, N. M., Wärri, A., Dings, R. P. M., Airio, M., Smeds, A. I., \& Mäkelä, S. (2008). Dietary lariciresinol attenuates mammary tumor growth and reduces blood vessel density in human MCF-7 breast cancer xenografts and carcinogen-induced mammary tumors in rats. International Journal of Cancer, 123(5), 1196-1204. http://dx.doi.org/10.1002/ijc.23614 
Saleh, M. A., Clark, S., Woodard, B., \& Deolu-Sobogun, S. A. (2010). Antioxidant and free radical scavenging activities of essential oils. Ethnicity and Disease, 20(1), S1-78-82.

SAPINO, les produits de la forêt. Balsam Fir. www.sapino.com

Shibutani, S., Igarashi, K., Samejima, M., \& Saburi, Y. (2001). Inhibition ofTrichoderma cellulase activity by a stilbene glucoside fromPicea glehnii bark. Journal of Wood Science, 47(2), 135-140. http://dx.doi.org/10.1007/BF00780562

Shibutani, S., Samejima, M., \& Doi, S. (2004). Effects of stilbenes from bark of Picea glehnii (Sieb. et Zucc) and their related compounds against feeding behaviour of Reticulitermes speratus (Kolbe). Journal of Wood Science, 50(5), 439-444. http://dx.doi.org/10.1007/s10086-003-0583-1

Simard, F., Legault, J., Lavoie, S., Mshvildadze, V., \& Pichette, A. (2008). Isolation and identification of cytotoxic compounds from the wood of Pinus resinosa. Phytotherapy Research, 22(7), 919-922. http://dx.doi.org/10.1002/ptr.2416

Simard, S., Hachey, J. M., \& Collin, G. J. (1988). The variations of essential oil composition during the extraction process. The case of Thuja occidentalis L. and Abies balsamea (L.) Mill. Journal of Wood Chemistry and Technology, 8(4), 561-573. http://dx.doi.org/10.1080/02773818808070701

Smirnoff, W. A. (1972). Effects of volatile substances released by foliage of Abies balsamea. Journal of Invertebrate Pathology, 19 (1), 32-35. http://dx.doi.org/10.1016/0022-2011(72)90185-1

Soekamto, N. H., Achmad, S. A., Ghisalberti, E. L., Hakim, E. H., \& Syah, Y. M. (2003). Artoindonesianins X and Y, two isoprenylated 2-arylbenzofurans, from Artocarpus fretessi (Moraceae). Phytochemistry, 64 831-834.

Spoor, D. C. A., Martineau, L. C., Leduc, C., Benhaddou-Andaloussi, A., Meddah, Bo., Harris, C., \& Haddad, P. S. (2006). Selected plant species from the Cree pharmacopoeia of northern Québec possess anti-diabetic potential. Canadian Journal of Physiology and Pharmacology, 84(8-9), 847-858. http://dx.doi.org/10.1139/Y06-018

Stevanovic, T., Diouf, P. N., \& Garcia-Perez, M. E. (2009). Bioactive polyphenols from healthy diets and forest biomass. Current Nutrition, 38; Food Science, 5(4), 264-295. http://dx.doi.org/10.2174/157340109790218067

Thor, E., \& Barnett, P. E. (1974). Taxonomy of Abies in the southern Appalachians: variation in balsam monoterpenes and wood properties. Forest Science, 20(1), 32-40.

Tišler, V., Galla, E., \& Pulkkinen, E. (1986). Fractionation of hot water extract from Picea abies Karst. bark. Holz als Roh- und Werkstoff, 44(11), 427-431. http://dx.doi.org/10.1007/BF02609640

Toscano, U., Claudia, D., \& Pearce, R. B. (1991). Astringin and isorhapontin distribution in Sitka spruce trees. Phytochemistry, 30(7), 2183-2189. http://dx.doi.org/10.1016/0031-9422(91)83610-W

Tourino, S., Selga, A., Jimenez, A., Julia, L., Lozano, C., Lizarraga, D., \& Torres, J. L. (2005). Procyanidin fractions from pine (Pinus pinaster) bark: radical scavenging power in solution, antioxidant activity in emulsion, and antiproliferative effect in melanoma cells. Journal of Agricultural and Food Chemistry, 53(12), 4728-4735. http://dx.doi.org/10.1021/jf050262q

Tulloch, A. P. (1987). Epicuticular waxes of Abies balsamea and Picea glauca: occurrence of long-chain methyl esters. Phytochemistry, 26(4), 1041-1043. http://dx.doi.org/10.1016/S0031-9422(00)82346-8

Valimaa, A. L., Honkalampi-Hamalainen, U., Pietarinen, S., Willfor, S., Holmbom, B., \& von Wright, A. (2007). Antimicrobial and cytotoxic knotwood extracts and related pure compounds and their effects on food-associated microorganisms.International Journal of Food Microbiology, 115(2), 235-243. http://dx.doi.org/10.1016/j.ijfoodmicro.2006.10.031

von Rudloff, E. (1987). The volatile twig and leaf oil terpene compositions of three western North American larches, Larix laricina, Larix occidentalis, and Larix lyallii. Journal of Natural Products, 50(2), 317-321. http://dx.doi.org/10.1021/np50050a051

Witzell, J., \& Martin, J. A. (2008). Phenolic metabolites in the resistance of northern forest trees to pathogenspast experiences and future prospects. Canadian Journal of Forest Research, 38, 2711-2727. http://dx.doi.org/10.1139/X08-112

Willfor, S., Nisula, L., Hemming, J., Reunanen, M., \& Holmbom, B. (2004). Bioactive phenolic substances in 
industrially important tree species. Part 1: Knots and stemwood of different spruce species. Holzforschung, 58(4), 335-344.

Wood Biocon. (2007). Wood Material Science and Engineering Research Programme: Value-added products from barks of Nordic wood species using bioconversion and chemical technology. Conference. Stockholm.

Yang, D. Q., Wang, X. M., \& Hui Wan, S. J. (2004). A rapid method for evaluating antifungal properties of various barks. Forest Products Journal, 54(6), 37.

Yeşilada, E., Honda, G., Sezik, E., Tabata, M., Fujita, T., Tanaka, T., \& Takaishi, Y. (1995). Traditional medicine in Turkey. V. Folk medicine in the inner Taurus Mountains. Journal of Ethnopharmacology, 46(3), 133-152. http://dx.doi.org/10.1016/0378-8741(95)01241-5

\section{Copyrights}

Copyright for this article is retained by the author(s), with first publication rights granted to the journal.

This is an open-access article distributed under the terms and conditions of the Creative Commons Attribution license (http://creativecommons.org/licenses/by/3.0/). 